\title{
Carbon Nanotubes-Based Nanomaterials and Their Agricultural and Biotechnological Applications
}

\author{
Dinesh K. Patel ${ }^{\dagger}$, Hye-Been Kim ${ }^{\dagger}$, Sayan Deb Dutta, Keya Ganguly and Ki-Taek Lim *(D) \\ Department of Biosystems Engineering, The Institute of Forest Science, College of Agriculture and Life Sciences, \\ Kangwon National University, Chuncheon 24341, Korea; dineshbhud10@gmail.com (D.K.P.); \\ asd1266@naver.com (H.-B.K.); sayan91dutta@gmail.com (S.D.D.); gkeya14@gmail.com (K.G.) \\ * Correspondence: ktlim@kangwon.ac.kr \\ + Equivalent authors.
}

Received: 21 February 2020; Accepted: 31 March 2020; Published: 3 April 2020

\begin{abstract}
Carbon nanotubes (CNTs) are considered a promising nanomaterial for diverse applications owing to their attractive physicochemical properties such as high surface area, superior mechanical and thermal strength, electrochemical activity, and so on. Different techniques like arc discharge, laser vaporization, chemical vapor deposition (CVD), and vapor phase growth are explored for the synthesis of CNTs. Each technique has advantages and disadvantages. The physicochemical properties of the synthesized CNTs are profoundly affected by the techniques used in the synthesis process. Here, we briefly described the standard methods applied in the synthesis of CNTs and their use in the agricultural and biotechnological fields. Notably, better seed germination or plant growth was noted in the presence of CNTs than the control. However, the exact mechanism of action is still unclear. Significant improvements in the electrochemical performances have been observed in CNTs-doped electrodes than those of pure. CNTs or their derivatives are also utilized in wastewater treatment. The high surface area and the presence of different functional groups in the functionalized CNTs facilitate the better adsorption of toxic metal ions or other chemical moieties. CNTs or their derivatives can be applied for the storage of hydrogen as an energy source. It has been observed that the temperature widely influences the hydrogen storage ability of CNTs. This review paper highlighted some recent development on electrochemical platforms over single-walled CNTs (SWCNTs), multi-walled CNTs (MWCNTs), and nanocomposites as a promising biomaterial in the field of agriculture and biotechnology. It is possible to tune the properties of carbon-based nanomaterials by functionalization of their structure to use as an engineering toolkit for different applications, including agricultural and biotechnological fields.
\end{abstract}

Keywords: carbon nanotubes; electrochemical; agricultural; biotechnological; engineering toolkits

\section{Introduction}

Nanotechnology has an essential place in the progress of the latest technology, and is the leading investment field in all research fields. Nanotechnology provides an approach for inducing cell growth and forming a high-dimensional structure, like tissue engineering [1]. Among this nanotechnology, the prime spotlights are carbon nanotubes (CNTs) for industrial applications and implementations. CNTs are categorized into single-walled carbon nanotubes (SWCNTs) and multi-walled carbon nanotubes (MWCNTs) according to the number of layers present in the structure (Figure 1). SWCNTs consist of single-layer of graphene with the diameter range of $0.4-2 \mathrm{~nm}$, whereas MWCNTs comprise a multilayer of graphene sheet with the outer and inner diameter of 2-100 $\mathrm{nm}$ and 1-3 nm, respectively, being 0.2 to several microns in length [2]. The physicochemical characteristics comparison of SWCNTs and MWCNTs is shown in Table 1. CNTs have been recognized as an attractive material that can be 
utilized in a variety of fields depending on mechanical [3], electrical [4], and thermal characteristics [5]. CNTs are well suited for biological applications, where a high aspect ratio is required [6]. Initially, CNTs' works were primarily focused on electronic devices [7], displays [8], transistors [9,10], and so on, using the electrical characteristics of this nanomaterial. However, CNTs are considered a suitable material for several applications, ranging from biomedical [11] to agricultural technology [12-14]. The possible applications of CNTs are shown in Figure 2. Nanoparticles under $100 \mathrm{~nm}$ exhibit fascinating physical properties that open up new opportunities for application in various areas, including biological technology [15]. The development of new biocatalysts and drugs carrier from nanoparticles for bioengineering applications has advantages for grasping actions in the body, owing to their unique optical or electrical characteristics.

Carbon atom

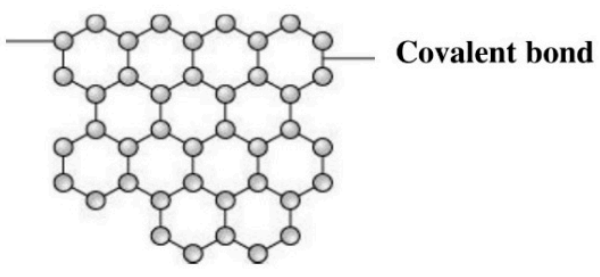

\section{Graphene sheet}

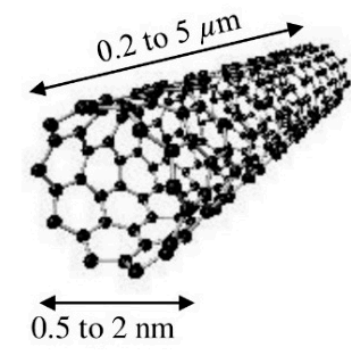

SWCNT

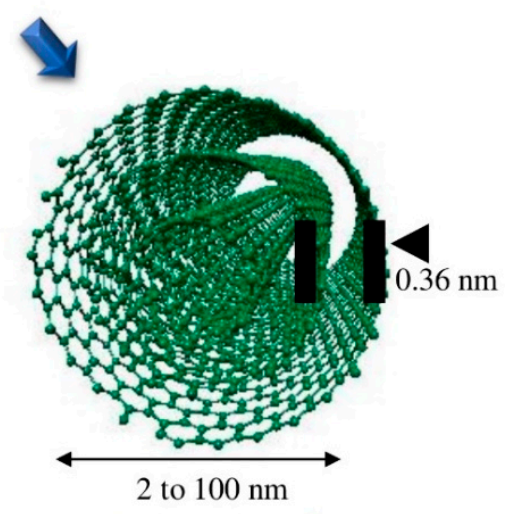

MWCNT

Figure 1. The conceptual diagram showing the general dimensions of the length and width of single-walled carbon nanotubes (SWCNTs) and multi-walled CNTs (MWCNTs) [2].

Table 1. Comparative study between single-walled carbon nanotubes (SWCNTs) and multi-walled carbon nanotubes (MWCNTs) [2].

\begin{tabular}{|c|c|}
\hline SWCNTs & MWCNTs \\
\hline Single layer of graphene & Multiple layer of graphene \\
\hline Expensive & Cheaper \\
\hline Thermal conductivity in the range of $6000 \mathrm{~W} / \mathrm{m} \cdot \mathrm{K}$ & Thermal conductivity in the range of $3000 \mathrm{~W} / \mathrm{m} \cdot \mathrm{K}$ \\
\hline $\begin{array}{l}\text { Semiconducting and metallic properties (excellent } \\
\text { field emission capability) }\end{array}$ & Low physical properties \\
\hline Bulk synthesis is difficult & Easy to synthesis in bulk \\
\hline Easily twisted & Difficult to twist \\
\hline Catalyst needed for synthesis & Manufactured without catalyst \\
\hline Low purity & High purity \\
\hline Less accumulation body & Greater accumulation in body \\
\hline More defection during the functionalization & Less defection, but hard to improve \\
\hline
\end{tabular}




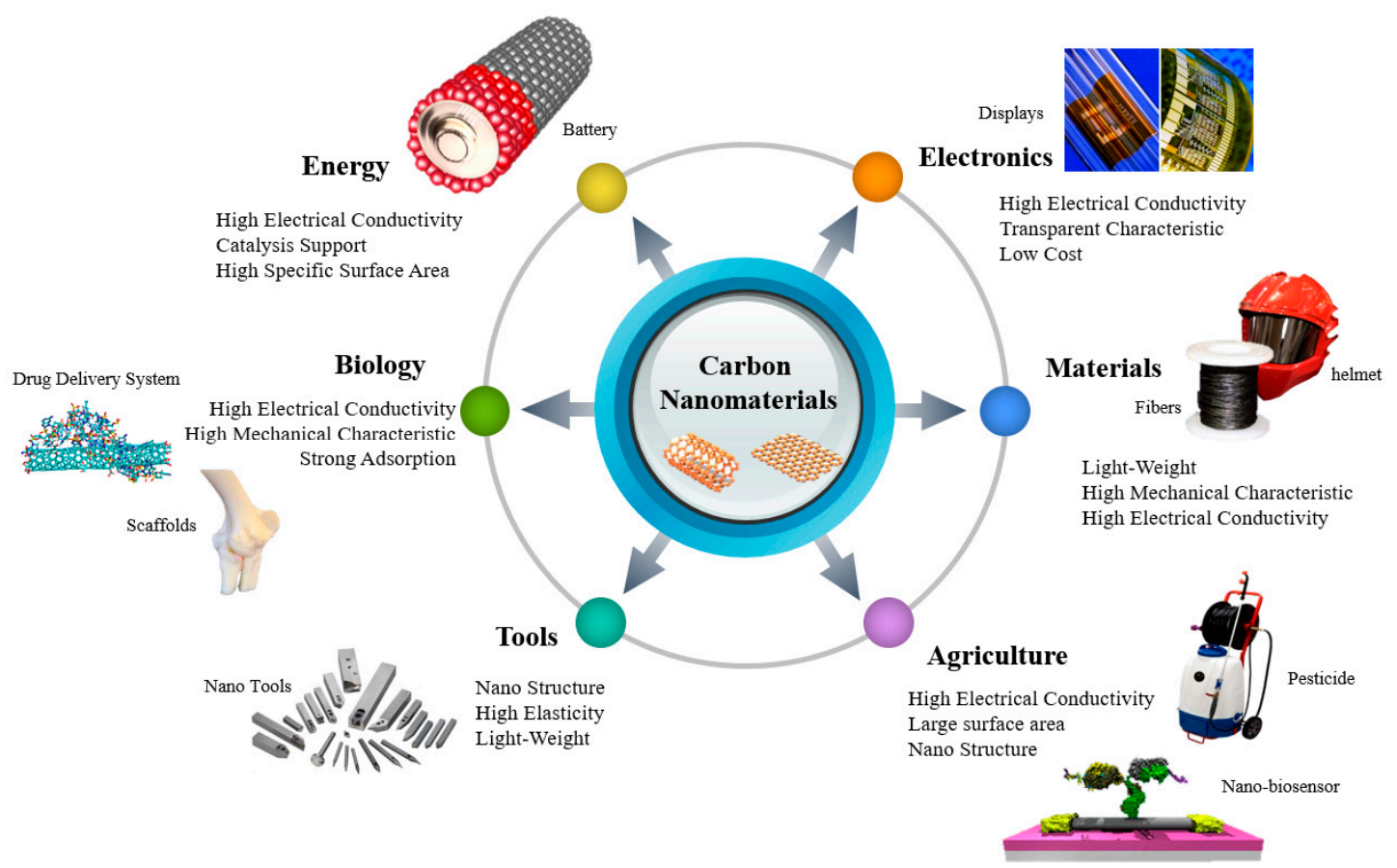

Figure 2. An overview of the properties of CNTs and with synthetic and transdermal applications. Various properties of CNTs enabling them to be used as the transdermal applications are depicted. Additionally, synthetic applications of CNTs are also depicted.

Various reports are available that emphasize the significance of CNTs to support bone growth by enhancing the mechanical properties of existing natural and synthetic polymers [16,17]. Currently, most of the studies on biological applications of CNTs-based and other carbon allotropes (graphene, fullerene) as biomaterials are focused on an approach to continuous interactions with living cells and tissues [17]. However, it has also been reported that cell/tissue interactions with CNTs can have adverse effects, which can cause a potential risk to human health [17]. Herein, we briefly described the synthesis and applications of carbon-derived nanomaterials in agricultural and biotechnological fields. The properties of CNTs are profoundly affected by their synthesis process. CNTs or their derivatives exhibited superior potential to promote the plant and growth. These nanomaterials can widely be explored in the fields of a nanosensor for the detection of the pathogens, as well as other bioresource fields, including battery, fuel cell, energy, and water purification.

\section{Synthesis of CNTs}

Various methods are available that are employed for the fabrication of CNTs from different carbon precursors. Each method has its advantages and disadvantages. Here, we briefly described some conventional methods utilized in the synthesis of CNTs with their merits and demerits.

\subsection{Arc Discharge}

This method is based on the potential difference between the two electrodes within a chamber. The graphite rod acts as an anode, and the migration of carbon particles migrated towards the cathode electrode, which is kept at a low temperature for the condensation of CNTs. The transition metals, such as $\mathrm{Co}, \mathrm{Ni}, \mathrm{Fe}$, and $\mathrm{Y}$, favor the formation of SWCNTs. The arc current sublimates the carbon precursor filled inside the anode and produces plasma at very high temperatures ( 4000-6000 K) [18]. However, other by-products are also generated during the synthesis of CNTs through the arc discharge method. Therefore, it is essential to control the purification step for the synthesis of CNTs [19]. The high-quality CNTs can be produced through this approach by using the suitable catalyst and optimizing the process conditions $[20,21]$. The pressure of the gas and the applied current in the chamber are also important 
variables. As the pressure increases, the production of CNTs increases. However, a decrease in the yield of CNTs is observed at a very high pressure.

\subsection{Laser Vaporization}

In this method, the shooting of the targeted graphite is performed at about $1200^{\circ} \mathrm{C}$ in a reaction furnace. As a consequence of this shooting, the vaporization of graphite has occurred, which is collected at a cold collector. Helium or argon gas is used for the carrier of the vaporized graphite, and the pressure of the reaction furnace is maintained at about 500 Torr [22]. Uniform SWCNTs can be produced in the presence of the transition metal catalysts such as $\mathrm{Co}, \mathrm{Ni}$, and $\mathrm{Fe}$. The laser evaporation method is the optimal state for the high yield and precise control of process parameters [23,24]. The diameter of SWCNTs produced by the laser evaporation approach is profoundly affected by the furnace temperature and is generated in a narrow range with a diameter distribution of $\sim 1.2-1.4 \mathrm{~nm}$ [25]. The diameter distribution of the produced materials can be easily tuned by changing the chemical compositions of the target, as well as the process gas [24].

\subsection{Chemical Vapor Deposition (CVD)}

A supportive catalyst is required for the synthesis of CNTs through the chemical vapor deposition (CVD) method from their carbon precursor. The decomposition of the injected gas accomplishes the synthesis of CNTs via heat and plasma [26,27]. The thermal CVD synthesis method is well-suited for the synthesis of highly pure materials, and the microstructures of the synthesized materials can be controlled in this method [28]. The temperature plays an essential role in the growth rate, diameter, and density of the developed CNTs [29]. An enhancement ( 4 times) in the CNTs growth rate $(0.5-2.0 \mu \mathrm{m} / \mathrm{min})$ was noted by increasing the temperature from $750{ }^{\circ} \mathrm{C}$ to $950{ }^{\circ} \mathrm{C}$. It has been noted that $\mathrm{Ni}$ has better catalytic activity than $\mathrm{Co}$ and $\mathrm{Fe}$ [30]. The thickness of the catalyst also has a significant influence on the density, diameter, and length of the developed CNTs [31]. It was noted that the thicker catalyst layer facilitates the formation of the larger diameter of CNTs with a shorter length. Further, the temperature gradients and catalyst-substrate interactions between catalyst particles are crucial for determining the CNTs' growth mechanism [32]. The plasma CVD method has an advantage over the thermal CVD method [33], where a relatively lower temperature is required for the synthesis of CNTs [34].

\subsection{Vapor Phase Growth}

In the vapor phase growth process, the synthesis of CNTs takes place in the presence of the reaction gases and an organometallic catalyst in a reaction furnace without the assistance of any substrate. The graphite surface having CNTs is widely affected by the crystal face of the catalyst particle, whereas the diameter of the nanotubes is profoundly influenced by the size of the decomposed catalyst particles. This method has an advantage for the synthesis of CNTs [35].

The comparative study of these methods, including arc discharge, laser vaporization, chemical vapor deposition, and vapor phase growth, with their merits and demerits, are summarized in Table 2. 
Table 2. A comparative study of different types of methods used in the synthesis of CNTs.

\begin{tabular}{|c|c|c|c|c|}
\hline Methods & Arc Discharge & Laser Vaporization & $\begin{array}{l}\text { Chemical Vapor } \\
\text { Deposition }\end{array}$ & Vapor Phase Growth \\
\hline Condition & $\begin{array}{l}\text { Voltage } 25-60 \mathrm{~V} \\
\text { Current } 50-100 \mathrm{~A}\end{array}$ & $\begin{array}{l}\text { Temperature } 1200^{\circ} \mathrm{C} \\
\text { and pressure } 500 \text { Torr }\end{array}$ & $\begin{array}{l}\text { Temperature } 550-1000^{\circ} \mathrm{C} \\
\text { at atmospheric pressure }\end{array}$ & $\begin{array}{l}\text { Supplying reaction gas } \\
\text { and organometallic } \\
\text { catalyst in the reactor }\end{array}$ \\
\hline Yield & $30-90 \%$ & $\sim 70 \%$ & $20-100 \%$ & - \\
\hline $\begin{array}{l}\text { Carbon } \\
\text { Source }\end{array}$ & Graphite & Graphite & $\begin{array}{l}\text { Fossil-based hydrocarbon, } \\
\text { botanical hydrocarbon }\end{array}$ & Hydrocarbon \\
\hline Advantage & $\begin{array}{l}\text { Excellent } \\
\text { crystallinity }\end{array}$ & $\begin{array}{l}\text { High quality, } \\
\text { high yield compared } \\
\text { with arc discharge }\end{array}$ & Can be controlled & $\begin{array}{l}\text { Could be produce in } \\
\text { bulk }\end{array}$ \\
\hline Disadvantage & $\begin{array}{l}\text { Difficult to obtain } \\
\text { uniform length } \\
\text { nanotube, } \\
\text { contain a large } \\
\text { amount of } \\
\text { impurities }\end{array}$ & $\begin{array}{l}\text { Difficult to } \\
\text { maintenance, } \\
\text { low production, } \\
\text { expensive }\end{array}$ & $\begin{array}{l}\text { Affected the temperature } \\
\text { change and position, } \\
\text { relatively crystallinity }\end{array}$ & - \\
\hline References & {$[36,37]$} & {$[18,23]$} & {$[21,22]$} & [34] \\
\hline
\end{tabular}

\section{Properties}

\subsection{Electrical Properties}

Several studies have determined the electrical properties of CNTs based on the concept of a helical structure, as proposed by Iijima [18]. The semiconductor or metallic potentials of CNTs are governed by the diameter and helicity of the graphene. As shown in Figure 3, CNTs can be made by the rolling of a graphene sheet such that the equivalent lattice parts of the two hexagons coincide [38,39]. The roll-up vector $\mathrm{Ch}=\mathrm{na} 1+\mathrm{ma} 2=(\mathrm{n}, \mathrm{m})$ can control the diameter and helicity of the SWCNTs, where $\mathrm{n}$ and $\mathrm{m}$ are integers, and a1 and a2 are graphene lattice vectors [40]. The two integers ( $\mathrm{n}$ and 0 ) correspond to the number of unit vectors along the direction of the grid [41]. The two $(n, 0)$ exponents can be used to predict the electronic structure of SWCNTs. As shown in Figure 3, the chiral angle in the zigzag direction of the unit vector (a1, a2) of the hexagonal honeycomb grating is $\theta=0^{\circ}$ and the armchair tube corresponds to $\theta=30^{\circ}$ [42]. When $(n, n)$, the nanotube is called "armchair," and when $(n, 0)$, the nanotube is called "zigzag" (armchair: conductor properties; zigzag: semiconductor properties). There are several reports available that show the high conductivity of CNTs [43-45]. It has been noted that the resistance of metal SWCNTs in rope form was about $10^{-4} \Omega \mathrm{cm}$ at $300 \mathrm{~K}$. This value is a higher value than the current known conductive carbon fiber [46,47].

\subsection{Thermal Properties}

CNTs have better thermal conductivity than the diamond ( $\mathrm{sp}^{3}$ hybridized) owing to the presence of $\mathrm{sp}^{2}$ hybridized covalent bonds [48,49]. The thermal conductivity of CNTs is widely influenced by the temperature and phonon mean-free path. The thermal conductivity value of SWCNTs is noted in the range of $1800-6000 \mathrm{~W} / \mathrm{m} \cdot \mathrm{K}$ at room temperature. This value is higher than the diamond, $3320 \mathrm{~W} / \mathrm{m} \cdot \mathrm{K}$, which was known for the highest thermal conductive material. However, the thermal conductivity of MWCNTs is noted to be $3000 \mathrm{~W} / \mathrm{m} \cdot \mathrm{K}[50,51]$. The thermal properties of CNTs are also influenced by the functionalization [52]. The thermal conductivity of the polymer can be easily modified by incorporating CNTs in their matrix, and this potential is widely affected by the nature of CNTs $[36,37,53]$.

\subsection{Mechanical Properties}

The strong covalent bond $\left(\mathrm{sp}^{2}\right)$ enables the high mechanical strength of CNTs. It undergoes the bending condition without damaging its original structure after applying the strong force and returns the original condition as the force is removed from the surface. The average Young's modulus values of CNTs with the diameter ranging from 1.0 to $1.5 \mathrm{~nm}$ were found to $1.25 \mathrm{TPa}$, which is higher the in-plane modulus value of graphite $[54,55]$. The elastic properties of SWCNTs are overwhelmingly 
affected by the chirality and the diameter of CNTs $[56,57]$. The mechanical strength of CNTs varies with the size of the nanoparticles, and has a considerable impact on the mechanical strength of the composites [58,59]. Owing to the excellent characteristic, CNTs can be used not only as a reinforcing material, but also as an additive material.

(a)

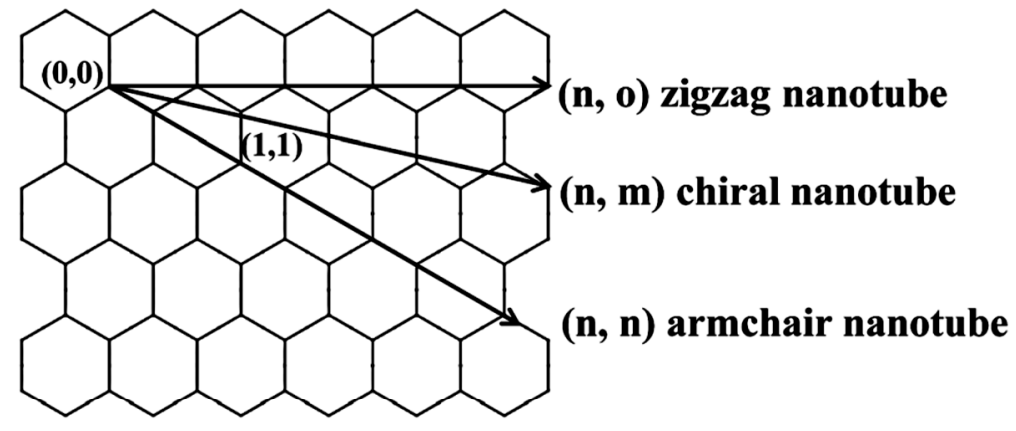

(b)

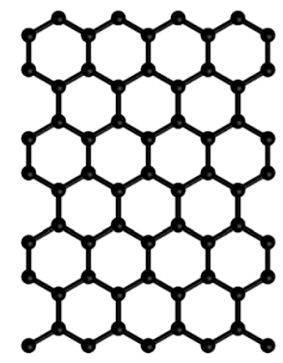

(c)

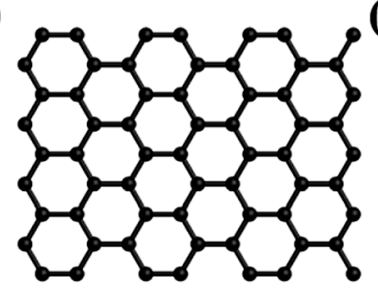

(d)

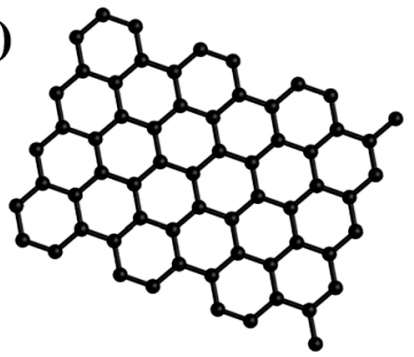

Figure 3. (a) Schematic representation of how a graphene sheet is rolled to form three chiralities of nanotubes: (b) zigzag, (c) armchair, and (d) chiral nanotubes [39].

\section{Application of CNTs}

\subsection{Agriculture Applications}

The unique properties of nanomaterials such as small size, large surface area, and reactivity provide excellent opportunities for its use in the agricultural sector. The foremost applications of CNTs in the agricultural field include seed germination, early plant growth, pesticides, and biosensor diagnostics and analysis. The potential toxicity of nanomaterials has not yet been widely investigated [60-62]. Here, we described the potential utilization of CNTs in the agricultural sector by considering some selected, but significant works.

\subsubsection{CNTs in Plant Growth}

The applications of the nanomaterials as a promoter for plant and crop growth have received a significant amount of interest from the scientific community. It has been noted that CNTs can penetrate the thick seed coat and activate the water uptake process, which might be responsible for rapid seed germination and early growth [63]. Mondal and coworkers measured the seeds germination rate of Brassica juncea (mustard) in the presence of MWCNTs having a diameter of $\sim 30 \mathrm{~nm}$. A significant enhancement in the seeds germination rate, $\mathrm{T}_{50}$ (time for $50 \%$ germination), was noted in the presence of a low concentration of oxidized MWCNTs compared with the control. They observed that the moisture content was significantly high in oxidized MWCNTs-treated seeds than in the untreated condition, indicating that oxidized MWCNTs facilitated the water-absorbing potential of the seeds for rapid regeneration. The high water content in oxidized MWCNTs-treated seeds was the result of the easy penetration ability of these functionalized CNTs. However, the exact mechanism for the rapid growth of seeds in oxidized MWCNTs is still unclear. It is well known that aquaporins facilitate the water uptake inside the cells. The efficiency of aquaporin is profoundly affected by several factors like $\mathrm{pH}$; concentrations of the heavy metal ions; osmotic pressure; and water channel expression 
genes such as plasma membrane intrinsic protein (PIP), small basic intrinsic protein (SIP), and so on. Aquaporin also reduces the flow of different ions through membranes and controls the electrochemical potential of the membrane. This potential of aquaporins is expected to be the key reason for the rapid regeneration of seeds in the presence of oxidized MWCNTs [64]. Several studies have been done to explore the effects of the various carbon nanomaterials (CNMs), including MWCNTs, fullerenes, and carbon nanohorns on different plants such as tomato, rice, cucumber, onion, radish, corn, soybean, switchgrass, and broccoli [65-71]. It was noted that 50-100 mg/L concentrations of CNMs are sufficient to penetrate the seeds for fast germination and growth rates $[65,66]$. Various factors such as size, shape, surface structure, solubility, and concentrations, as well as the presence of the functional groups, have significant contributions towards the toxicity and pathology caused by CNTs in the germination of seeds [61,72]. Functionalized carbon nanotubes (F-CNTs) also have an important aspect of being used as a nanomaterial to alter the seed germination and growth rates. Chang and coworkers have evaluated the toxic effects of CNTs (SWCNTs and MWCNTs) combined with cadmium (Cd) on wheat seedling growth. A significant reduction in total root length, root surface area, average root diameter, numbers of root hairs, and the dry weight of shoots and roots was observed in Cd-combined CNTs treatment groups than with Cd, as well as SWCNTs and MWCNTs treatment, indicating that Cd-combined CNTs remarkably inhibited wheat growth and development. Furthermore, a decrease in tubulins in the root was also noted. However, an enhancement in glutathione S-transferase and cytochrome P450 in the shoots and roots was observed in Cd-combined CNTs treatment groups, suggesting the improved defense ability of wheat seedling. It was interesting to see that the accumulation of $\mathrm{Cd}$ in shoot and root tissues was profoundly affected by the concentrations of CNTs. These results suggested that CNTs facilitated the toxicity of $\mathrm{Cd}$ to the wheat seedling. Therefore, the toxicity of CNTs should be remarkably considered with food security in the future with exposure of crops to Cd [73]. Transmission electron microscopy (TEM) morphologies of wheat plant cells under different conditions are shown in Figure 4a. The results indicated that CNTs had the potential to destroy the cell structure, and $\mathrm{Cd}$ highly influenced this ability. A comparative study has been done by Cano and coworkers to evaluate the effects of CNTs at various concentrations $(0,10$, and $100 \mathrm{mg} / \mathrm{kg})$ for the germination and growth of corn seeds. For this, they have taken pure SWCNTs, OH-functionalized, and surfactant stabilized SWCNTs [74]. The microwave-induced heating approach was explored to determine CNTs in different parts of the germinated seeds. They noted that the accumulation of F-CNTs in roots, stems, and leaves was independent of the functional groups present in CNTs, but dependent on the volume and composition of the soil. No significant difference in the plant physiological stress was observed between SWCNTs and the control. The effects of CNMs on plant and crop growth are also summarized in Table 3. Bioenergy crops are a suitable candidate for use in energy production. For bioenergy applications, plants should produce a high amount of biomass and resist adverse environmental conditions. The effects of CNMs on seed germination, biomass accumulation, and salt stress response of bioenergy crops (sorghum and switchgrass) were studied by Pandey et al. [75]. A significant enhancement in the germination rate was observed in CNTs-treated crops compared with the control, indicating the positive effect of nanomaterial towards crop growth. Approximately $73.68 \%$ and $31.57 \%$ enhancement in shoot biomass was noted in switchgrass seedlings with the exposure of CNTs for 10 days at concentrations of 50 and $200 \mu \mathrm{g} / \mathrm{mL}$, respectively. A significant reduction in salt $(\mathrm{NaCl})$-induced stress symptoms was noted in CNMs-treated media compared with the control, demonstrating that CNMs have the potential to protect the plants against salt-induced stress in the saline growth medium. The effects of CNTs on the growth rate of switchgrass and sorghum seedlings at different concentrations after 10 days of exposure are given in Figure $4 b, c$. 
(a)

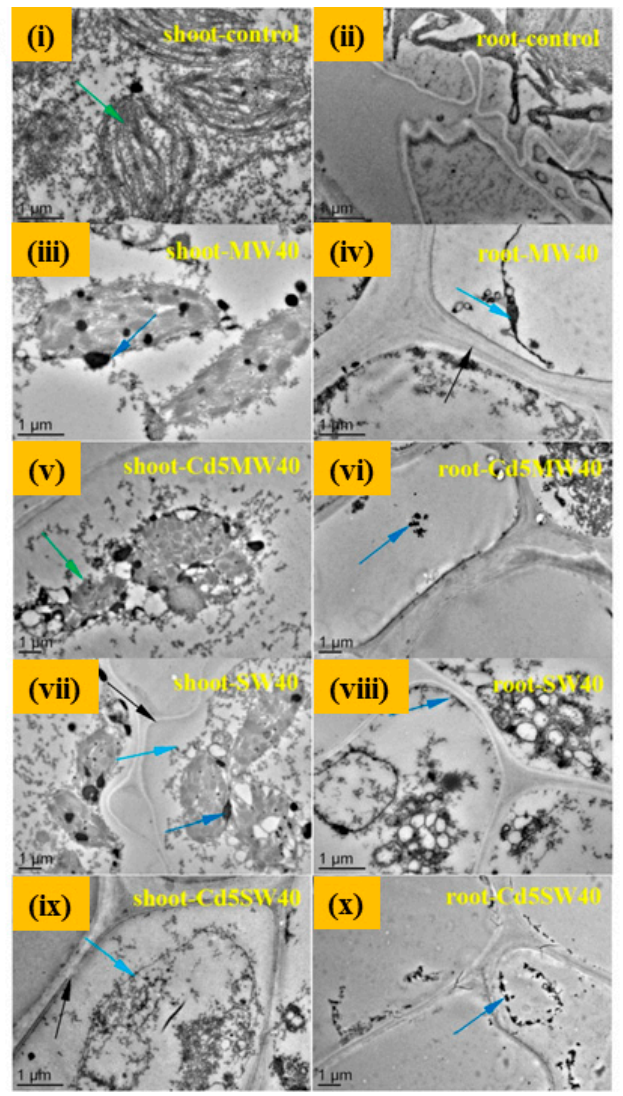

(b)

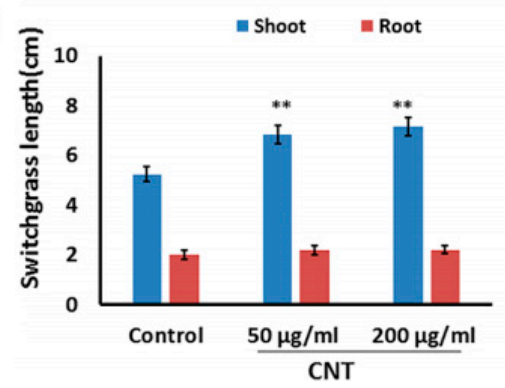

(c)

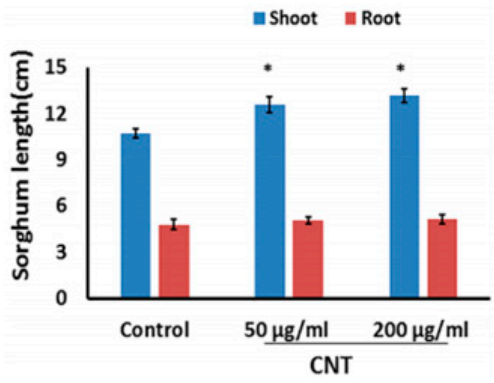

Figure 4. (a) Transmission electron microscopy images of plant cells. Green arrows indicate chloroplasts in (i,v); black arrows indicate the cell wall for (iv,vii,ix); navy blue arrows indicate CNTs deposition for (iii,vi,vii,viii,x); and light blue arrows indicate cell membrane in (iv,vii,ix) [73]. (ii) Growth enhancement on (b) switch grass and (c) sorghum seedlings by exposure to carbon-based nanomaterials. Effects on growth of bioenergy crops by CNTs added to growth medium. Measurements were performed on 10-day-old seedlings ( $\mathrm{n}=30$ for both sorghum and switch grass). ( ${ }^{*} p<0.05$ and ${ }^{* *} p<0.01$ ) [75].

\subsubsection{Biosensor}

The biosensor is a device that quantitatively measures the molecules reacting in a solution having analytes to be measured by utilizing their reacting properties with a specific substance. The excellent physicochemical potentials make CNMs an ideal material for sensing applications to detect the pathogens [76,77]. In comparison with the commercially available sensors such as metal oxides, silicon, and so on, CNTs-based biosensors have significant advantages, such as high sensitivity (large surface area ratio), excellent luminescence properties, fast response time, and high stability [78]. Different types of sensors are explored for monitoring the pollutant/species present in the medium. Biosensors are utilized to detect compounds such as aromatic and organic compounds and halogenated pesticides. Solid-state electrochemical sensors are suitable for the chemical gas sensor from their sensitivity, reproducibility, and power consumption. The basic principle of a biosensor for soil diagnosis is to determine the relative activity of favorable and unfavorable microbe's presence in the soil based on differential oxygen consumption owing to respiration. Surface plasmon resonance (SPR) phenomenon is also explored for the development of the biosensor from metallic nanoparticles [79]. Nano-biosensors are being rapidly explored in the agricultural sector and food processing. CNTs-based optical sensors were developed to monitor the real-time detection of pathogenic bacteria [80], organophosphate chemical warfare agents and pesticides [81], toxic materials, and proteins [82]. The one-dimensional (1D) properties of CNTs facilitate the ultrasensitive detection of analyte because all atoms are surface atoms, and minor perturbations in the chemical environment can dramatically change the electrical 
or optical properties [83]. This property plays a vital role in the monitoring of the optical sensor under various circumstances [84]. Among different biosensors, electrochemical biosensors are the most popular because of their excellent conductivity and electro-catalysis, high surface, and volume ratio [85]. The transfer of the electrons occurred in these biosensors [86-88]. CNMs have the potential to improve the response characteristics and can act as the immobilization matrices for the bio-receptors [89]. A significant decrease in the response time was observed in MWCNTs-coated electrodes used as a sensor [90]. An enhancement in the detection limits was noted in Au-MWCNTs nanocomposite, and it can detect concentrations up to $0.1 \mathrm{nM}$ [91]. Enzymes are considered as a suitable substrate for the development of the biosensors. CNTs have been utilized as a support for the immobilization of enzymes in nanostructured devices. Scholl and coworkers have developed the thin film of CNTs for enhancing the enzymatic potential of penicillinase for biosensing applications. The presence of CNTs in the developed film not only altered the catalytic potential of penicillinase, but also facilitated their enzymatic activity. ConCap responses curves for penicillin $\mathrm{G}$ detection through the fabricated films are shown in Figure 5. Recently, Yang et al. [92] have reported a composite skin patch with a high-performance flexible sensor consisting of $\mathrm{Ag} / \mathrm{CNT} / \mathrm{PDMS}$ for monitoring of the heartbeat as well as breath during active labor (Figure 6). Owing to the presence of CNTs, the wrinkled patch is highly sensitive and conductive. This could potentially be used in prophylactic medicine for monitoring of fever or hyperthermia caused by specific pathogens. The biosensors developed with CNTs indicate regular steps of the distinct output signal for all concentration ranges compared with the control. These changes may directly influence the potential and performance of the developed sensor in terms of their sensitivity and coefficient of determination $\left(R^{2}\right)$ [93].

Table 3. The effects of different carbon nanomaterials (CNMs) on plant and crop growth.

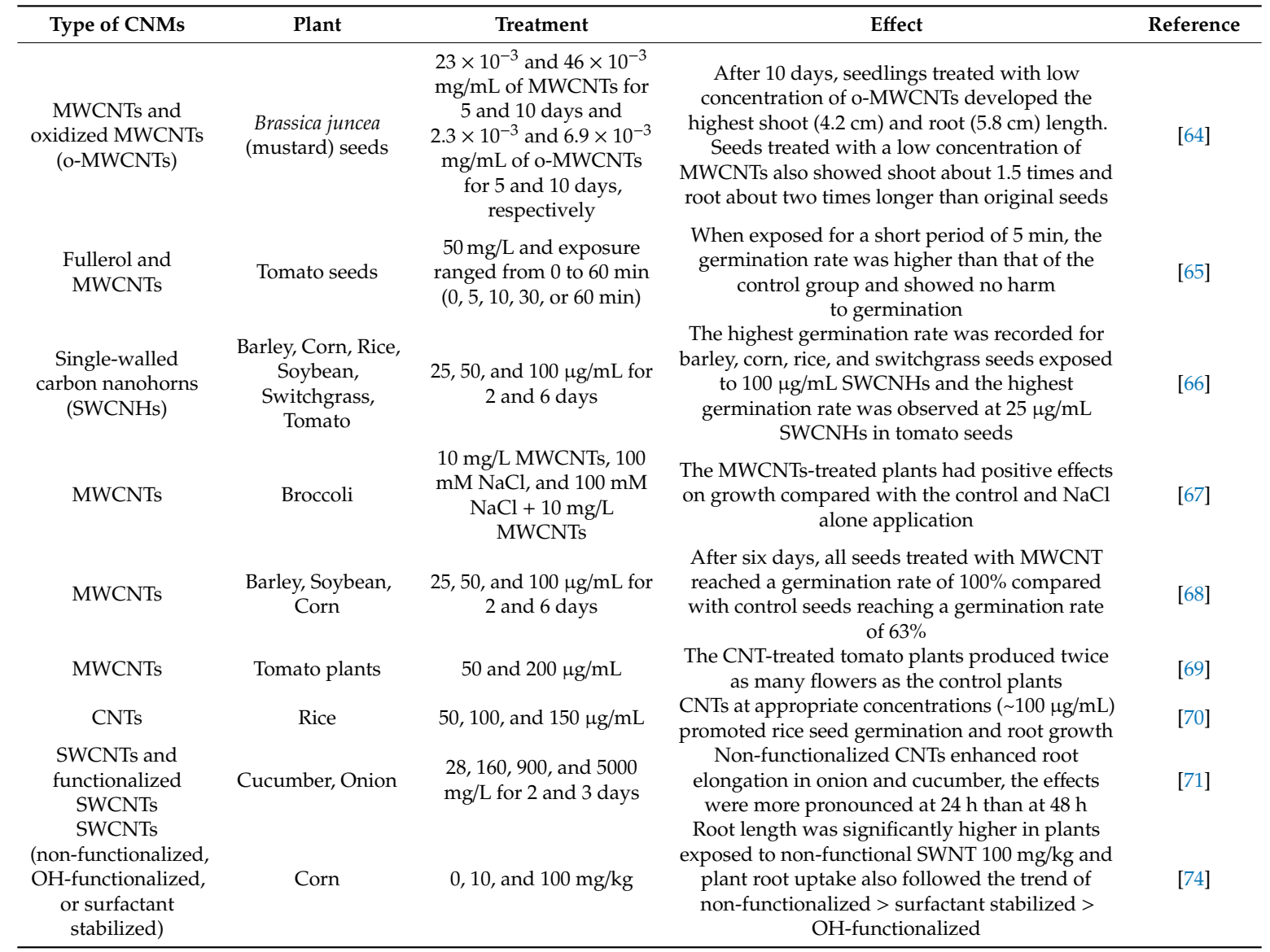



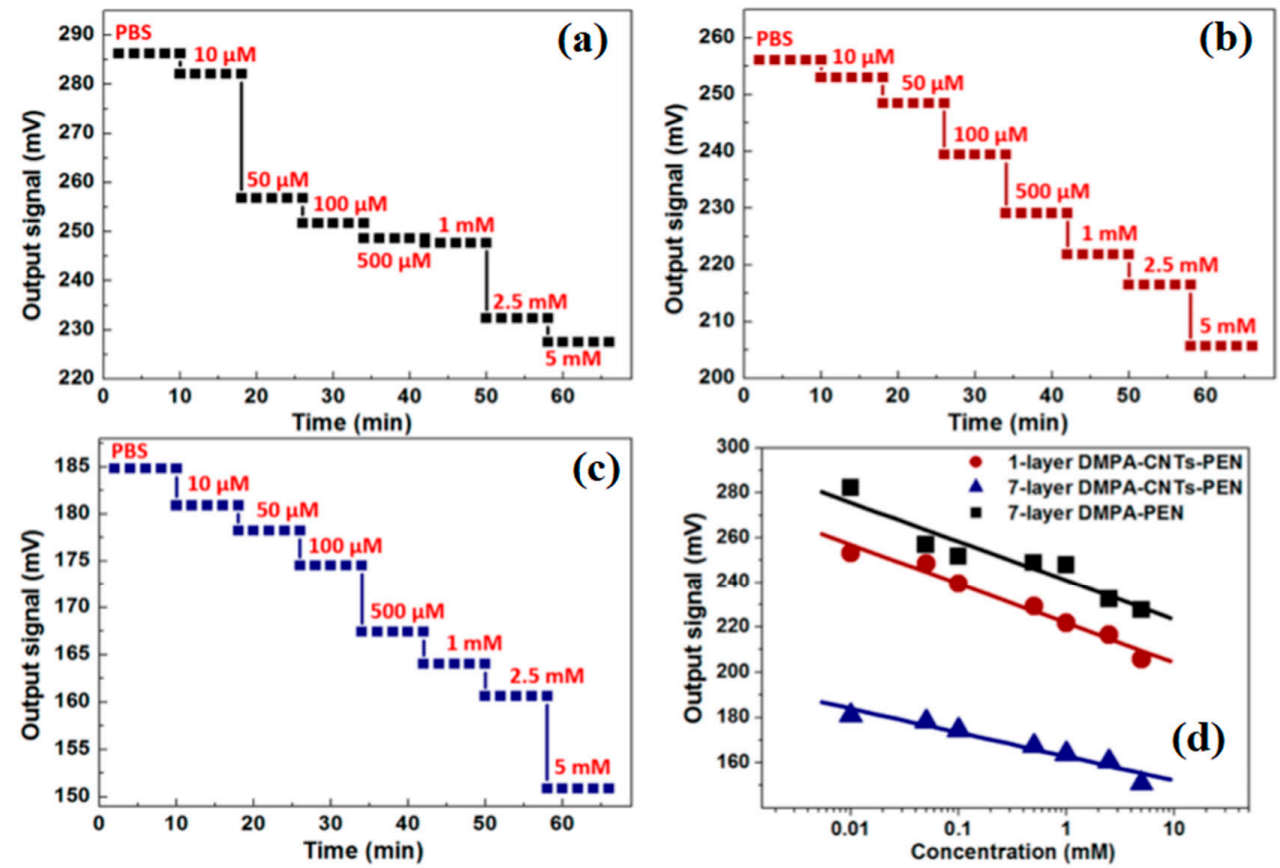

Figure 5. ConCap response curves toward penicillin G detection at different concentrations for LB film-incorporated EIS sensors: (a) seven-layer DMPA-penicillinase; (b) one-layer DMPA-CNTs-PEN; and (c) seven-layer DMPA-CNTs-PEN. (d) Calibration curve of ConCap responses for the LB films correlated with penicillin concentrations [93].

\subsubsection{Pesticide Analysis}

The high adsorption properties of CNTs are utilized for extraction techniques such as solid-phase extraction (SPE) and solid-phase micro-extraction (SPME) [94]. SPE technology is one of the most widely used extraction methods for environmental, food, and biological sample pretreatment. Several studies have been done showing the potential of MWCNTs as a promising adsorbent for the pre-concentration of cobalt, nickel, and lead ions [95,96]; organophosphate (OP) pesticides [97]; and chloro-phenols [98]. The recoveries of the analyte were also altered by the amount of MWCNTs and the treatment conditions, indicating that, by varying the sample conditions, they could be extended to other analytes and other types of food samples [99]. SPE sorbent, based on nanoparticles, demonstrates the potential for adequate enrichment and sensitive analysis of metal ions in a variety of media [100,101]. The effects of the CNMs in the SPE technique are also given in Table 4. An enhancement in the extraction efficiency was noted in SWCNTs- or MWCNTs-coated SPME fiber. The development of fiber coating technology for high-efficiency extraction of the analyte is considered an exciting research direction in SPME [102]. Higher extraction efficiency, precision, and accuracy were observed in SWCNTs-coated fiber from the targeted samples [100]. It has been noted that CNTs-coated fibers have more extraction efficiency than the commercially available PDMS $[103,104]$. Saraji et al. synthesized CNTs/SiO${ }_{2}$ nanohybrids for SPME coating and evaluated their extraction efficiency for some organophosphorus pesticides (OPPs) in vegetables, fruits, and water samples [105]. Gas chromatography-corona discharge ion mobility spectrometry was applied for the detections of the OPPs. Significant enhancement in the adsorption capacity and mass transfer rate was observed in $\mathrm{CNTs} / \mathrm{SiO}_{2}$-coated SPME compared with the commercial SPME fibers (PA, PDMS, and PDMS-DVB), indicating their improved extraction efficiency. For water samples, the detection limits range was $0.005-0.020 \mu \mathrm{g} / \mathrm{L}$, and the quantification limits were 0.010 and $0.050 \mu \mathrm{g} / \mathrm{L}$, with excellent linearity in the range of $0.01-3.0 \mu \mathrm{g} / \mathrm{L}$ for the samples. The spiking recoveries range was from $79( \pm 9)$ to $99( \pm 8)$. Therefore, the developed materials have the potential and can be applied for the analysis of OPPs in real samples [106]. The influence of the CNMs in the SPME technique is also summarized in Table 5. Feria and colleagues have determined 
the presence of different types of pesticides in virgin olive oils using MWCNTs and carboxylated c-SWCNTs. It was interesting to note that the c-SWCNTs exhibited better sorbent capabilities than those of MWCNTs owing to the presence of carboxyl functional groups in their structure, which facilitates better interactions between pesticides and CNTs. A comparison of the performance of c-SWCNTs and MWCNTs for the detection of different pesticides from virgin oil samples is shown in Figure 7a. The bar diagram demonstrates the better sorbent potential of c-SWCNTs than MWCNTs for different kinds of pesticides from the selected samples owing to the presence of the different functional groups. The effect of the number of c-SWCNTs $(10$ and $50 \mathrm{mg}$ ) on the analytical signal for different pesticides is shown in Figure $7 \mathrm{~b}$. An enhancement in the peak area was observed by increasing the number of c-SWCNTs for all analytes up to $30 \mathrm{mg}$. Furthermore, a decrease in the peak value was noted after a $30 \mathrm{mg}$ dose of c-SWCNTs owing to non-quantitative elution of the retained analytes [107].
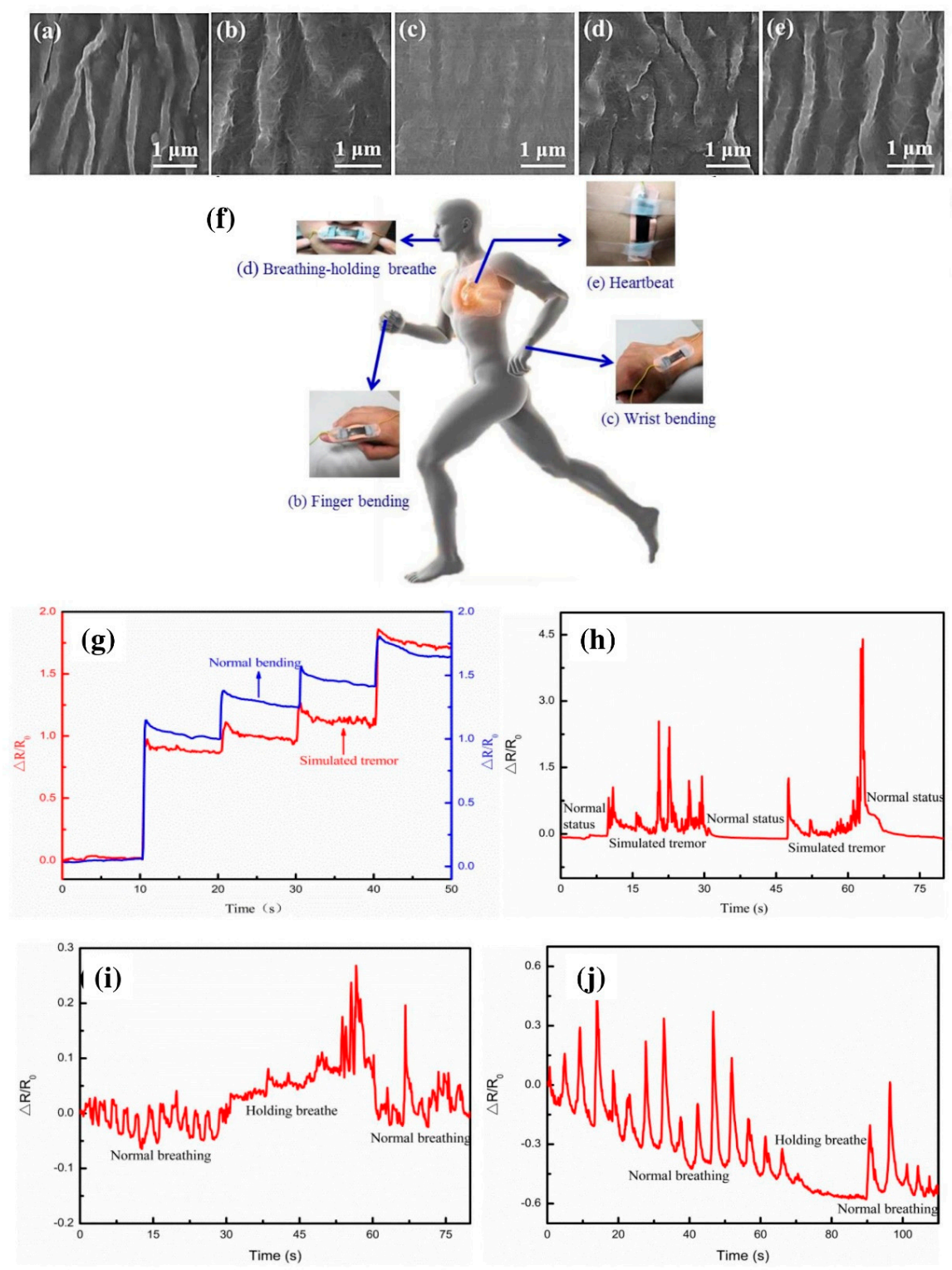

Figure 6. Ag-CNT-PDMS-based wearable sensors for monitoring the physiological conditions of the human body. (a-e) SEM morphologies of the wrinkled CNTs (left) and Ag/CNT/PDMS nanocomposite films under variant strain and release conditions $(1 \mu \mathrm{m})$. (f) Schematic illustration of sensor location and its application. (g) Signals received from the finger-bending involving the normal bending (blue) and stimulated bending (red). (h-j) Signal from wrist, upper lip, and chest showing the significant change in peak [92]. 
Table 4. The effects of CNMs in the solid-phase extraction (SPE) technique.

\begin{tabular}{|c|c|c|c|c|c|}
\hline CNTs & Analyte & Sample & $\begin{array}{l}\text { CNTs Amount } \\
\text { (mg) }\end{array}$ & Recovery (\%) & Reference \\
\hline MWCNTs & $\begin{array}{l}\text { Disulfoton sulfoxide, ethoprophos, } \\
\text { disulfoton, terbufos sulfone, } \\
\text { cadusafos, dimethoate, terbufos, } \\
\text { chlorpyrifos-methyl, fenitrothion, } \\
\text { malaoxon, pirimiphosmethyl, } \\
\text { malathion, chlorpyrifos, disulfoton } \\
\text { sulfone, and fensulfothion }\end{array}$ & $\begin{array}{l}\text { Water (run-off, } \\
\text { mineral, and tap } \\
\text { water) }\end{array}$ & 130 & $67-107$ & [94] \\
\hline $\begin{array}{c}\text { GO-MCNTs- } \\
\text { diethylenetriamine }\end{array}$ & $\mathrm{Cr}(\mathrm{III}), \mathrm{Fe}(\mathrm{III}), \mathrm{Pb}(\mathrm{II})$, and $\mathrm{Mn}$ (II) ions & Wastewater & 30 & 95 & [95] \\
\hline MWCNTs & $\begin{array}{l}\text { Organophosphate } \\
\text { 4-Chlorophenol, 3-chlorophenol, }\end{array}$ & Garlic & 1.2 & $97-104$ & [97] \\
\hline MWCNTs & $\begin{array}{l}\text { dichlorophenol, trichlorophenol, and } \\
\text { pentachlorophenol }\end{array}$ & River water & 300 & $93-117$ & [98] \\
\hline MWCNTs & $\begin{array}{l}\text { Tolclofos-methyl, fenitrothin, } \\
\text { malathion, phorate, diazinon, } \\
\text { isocarbophos, and quinalphos } \\
\text { phenamiphos }\end{array}$ & Peanut oil & 100 & $86-115$ & [99] \\
\hline MWCNTs & $\begin{array}{l}\text { Ethoprophos, diazinon, fenitrothion, } \\
\text { malathion, and phosmet }\end{array}$ & $\begin{array}{l}\text { Agricultural soil, } \\
\text { forestal soil, and } \\
\text { ornamental soil }\end{array}$ & 100 & $54-91$ & [101] \\
\hline
\end{tabular}

Table 5. The effects of CNMs in the solid-phase micro-extraction (SPME) technique.

\begin{tabular}{|c|c|c|c|c|c|}
\hline CNTs & Analyte & Sample & $\begin{array}{l}\text { CNTs Amount } \\
\text { (mg) }\end{array}$ & $\begin{array}{c}\text { Recovery } \\
(\%)\end{array}$ & Reference \\
\hline MWCNTs & Polybrominated diphenyl ethers (PBDEs) & $\begin{array}{l}\text { River water, waste } \\
\text { water, milk }\end{array}$ & $20 \mathrm{mg}$ & 90-119 & [102] \\
\hline SWCNTs & $\begin{array}{l}\text { Ethoprophos, terbufos, thiometon, tefluthrin, } \\
\text { iprobenfos, vinclozolin, octachlorodipropyl } \\
\text { ether, isofenphos, phenthoate, chlorfenapyr, } \\
\text { propiconazol, } \\
\text { Ethyl-p-nitrophenylthionobenzenephosphonate } \\
\text { (EPN), and } \lambda \text {-cyhalothrin }\end{array}$ & $\begin{array}{l}\text { Teas (green tea, } \\
\text { oolong tea, white tea, } \\
\text { and flower tea) }\end{array}$ & - & $75-118$ & [103] \\
\hline SWCNTs & $\begin{array}{l}\text { Hexachlorcyclohexan, } \\
\text { dichlorodiphenyldichloroethylene, } \\
\text { dichlorodiphenyldichloroethane, and } \\
\text { dichlorodiphenyltrichloroethane }\end{array}$ & Lake water & $2 \mathrm{~g}$ & $88-111$ & [104] \\
\hline $\begin{array}{l}\text { CNTs-silicon } \\
\text { dioxide }\end{array}$ & Diazinon, fenthion, parathion, and chlorpyrifos & $\begin{array}{l}\text { River water and } \\
\text { agricultural } \\
\text { wastewater, pear, } \\
\text { grape, and eggplant }\end{array}$ & $50 \mathrm{mg}$ & 79-99 & [105] \\
\hline
\end{tabular}

\subsection{Energy and Environmental Applications}

Works on CNTs in the field of bioresources are being studied as a material capable of overcoming the limitations of existing carbon materials or improving performance by using the high electrical conductivity of CNTs. As CNTs showed a high specific surface area, much research has been conducted into CNTs as an adsorbent for the removal of different contaminants such as $\mathrm{Zn}^{2+}$ and $\mathrm{Pb}^{2+}[108]$. CNTs nanocomposites have a wide range of applications depending on the type and combination of the target materials. Here, we have briefly described the nanotechnological applications of CNMs-based materials, including the battery, wastewater treatment, fuel cell, and energy storage, by considering some attractive works. 
(a)

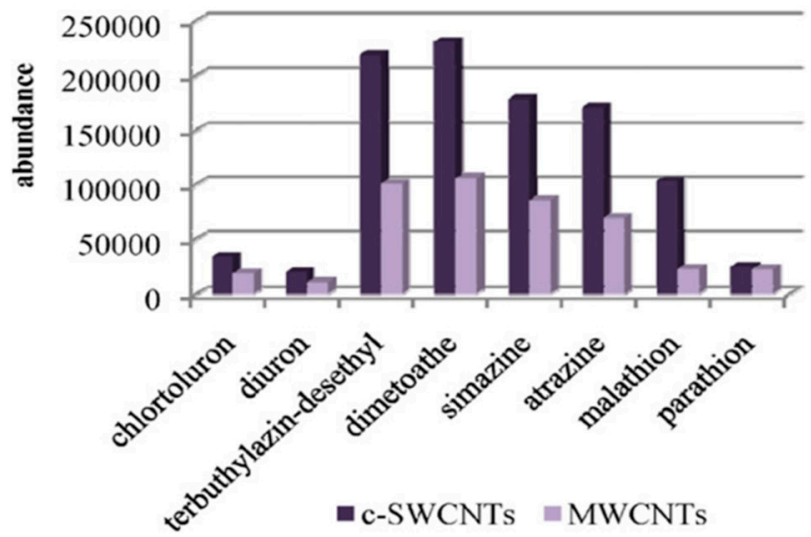

(b)

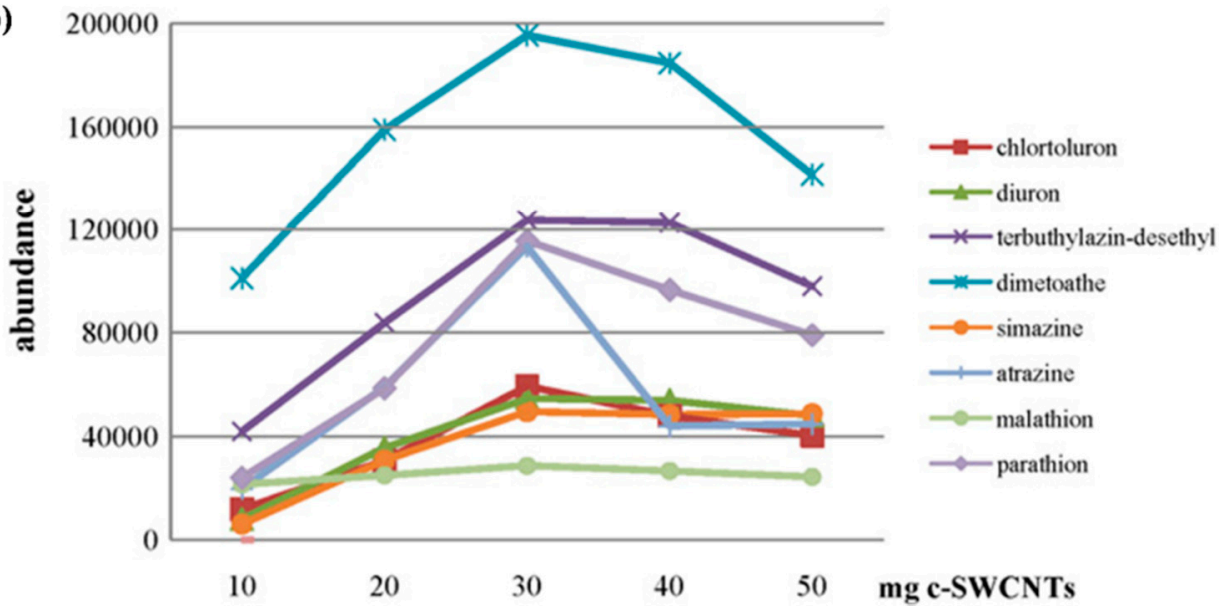

Figure 7. (a) Comparison of the performance of carboxylated (c)-SWCNTs and MWCNTs for the isolation of the selected pesticides from virgin olive oil samples. (b) Influence of the amount of c-SWCNTs packed in the solid-phase extraction (SPE) cartridge for the preconcentration of the selected pesticides from virgin olive oil samples [107].

\subsubsection{Battery}

Despite the rapid development of lithium-ion batteries, which have high power and energy density properties [109], numerous reports have focused on the application of CNTs for the energy sector [110-112]. The energy efficiency of CNTs is intensely affected by the synthesis method, shape, and structure. Maurin et al. showed that lithium was intercalated between the graphene layers of the MWCNTs prepared by arc discharge using micro-raman spectroscopy [113]. CNTs produced by the arc discharge method had a reversible capacity of $125 \mathrm{~mA} \cdot \mathrm{hg}^{-1}$ at a low current density [114], which has limited the practical application in lithium-ion batteries to some extent [115]. However, CNTs synthesized by chemical vapor deposition (CVD) showed the high reversible capacity of 340-640 mA.hg ${ }^{-1}$ at a low current density [116-118]. A comparative study was performed by Yang et al. using short CNTs (S-CNTs) and long CNTs (L-CNTs) synthesized through co-pyrolysis, as well as the CVD method, respectively, to evaluate the reversible capacity of both samples at a low current density. The reversible capacity of S-CNTs anode material was 266 and $170 \mathrm{~mA} \cdot \mathrm{hg}^{-1}$ at the current density of 0.2 and $0.8 \mathrm{~mA} \cdot \mathrm{cm}^{-2}$, respectively, which were twice that of L-CNTs anode materials. The surface film and charge-transfer resistant of S-CNTs anode materials were $1.7 \Omega$ and 3-4 $\Omega$, respectively, which is much lower than the L-CNTs (14 $\Omega$, and 31.2-61.2 $\Omega$ ) anode materials, indicating higher electrochemical activity [119]. The holes in the graphene sheet allow lithium to diffuse better inside the CNTs and increase the capacity. The conductive SWCNTs were able to store about five times more lithium ions than semiconducting SWCNTs [120]. The high conductivity of CNTs also 
provides enhanced electron transfer with nanostructured anode material [121]. However, long-term stability has remained a challenging task. The electrochemical performance is highly dependent on the nanostructure, shape, and surface properties [122-126]. Lee et al. have developed CNT-Si composite anode with extremely stable long-term cycling and a discharge capacity of $2364 \mathrm{~mA} \cdot \mathrm{hg}^{-1}$ at a tap density of $1.103 \mathrm{~g} \mathrm{~cm}^{-3}$. The CNT-Si composite anode retained an excellent cyclic maintenance equivalent to $90 \%$ of the initial discharge capacity after 100 cycles. A two-sloped full concentration gradient (TSFCG), $\mathrm{Li}\left[\mathrm{Ni}_{0.85} \mathrm{Co}_{0.05} \mathrm{Mn}_{0.10}\right] \mathrm{O}_{2}$ cathode, was used to prepare the fuel cell configuration. The assembled fuel cell exhibited an energy density of $350 \mathrm{~W} \mathrm{~h} \mathrm{~kg}^{-1}$ with excellent capacity retention for 500 cycles at 1C [127]. The electrochemical performances of CNTs-based Li-ion batteries are given in Table 6.

Table 6. The electrochemical performances of CNTs-based Li-ion batteries. CVD, chemical vapor deposition.

\begin{tabular}{|c|c|c|c|c|c|c|}
\hline CNMs & Method & Current Density & $\begin{array}{c}\text { Initial } \\
\text { Discharge } \\
\text { Capacity } \\
\text { (mA h/g) }\end{array}$ & Cycles & $\begin{array}{c}\text { Residual } \\
\text { Reversible } \\
\text { Capacity } \\
(\mathrm{mA} \cdot \mathrm{h} / \mathrm{g})\end{array}$ & Reference \\
\hline CNTs-SnSb 0.5 & CVD & $50 \mathrm{~mA} / \mathrm{g}$ & 549 & 30 & 369 & [111] \\
\hline CNTs-LiCoO & CVD & $0.2 \mathrm{C}$ & 118 & 20 & 118 & [112] \\
\hline CNTs & arc discharge & $2 \mathrm{C}$ & 300 & 300 & 255 & [114] \\
\hline MWCNTs & arc discharge & $0.2 \mathrm{~mA} \mathrm{~cm}^{-2}$ & 117 & 30 & 113 & [115] \\
\hline Short CNTs & CVD & $0.8 \mathrm{~mA} \mathrm{~cm}^{-2}$ & 491 & 30 & 170 & [119] \\
\hline $\mathrm{Fe}_{2} \mathrm{O}_{3} / \mathrm{CNT}$-graphene foam & CVD & $200 \mathrm{~mA} / \mathrm{g}$ & 1190 & 10 & 900 & [122] \\
\hline CNTs-cobalt oxide & & $0.1 \mathrm{C}$ & 1250 & 100 & 530 & [125] \\
\hline $\mathrm{Zn}_{2} \mathrm{SnO}_{4} / \mathrm{CNT}$ & & $100 \mathrm{~mA} / \mathrm{g}$ & 1925.4 & 30 & 703.8 & [126] \\
\hline
\end{tabular}

\subsubsection{Wastewater Treatment}

Nanotechnology plays a vital role in water purification. CNTs can be used for the purification of wastewater [128]. Adsorption and degradation/detoxification is the key strategy for the removal of contaminant from the samples through CNTs. The functionalization of the material can improve the efficiency of CNTs for contaminants. It is possible to target a specific contaminant through the well-modified CNTs. A schematic representation of CNTs' modifications for the removal of contaminant from water and wastewater is shown in Figure 8. Design or modification of CNTs' properties may also assist in the separation of materials following the contaminant treatment process. Nanoparticle separation is facilitated by incorporating a magnetic component into CNTs [129]. It is easy to control the potential and current in the electrochemical technique for wastewater treatment $[130,131]$. Yang et al. have used a seepage carbon nanotube electrode (SCNE) reactor to improve the electrochemical wastewater treatment efficiency. The innovative concept behind the reactor design was that the overall mass transfer would be significantly improved via contaminant migration through the porous carbon nanotube electrode. The current efficiency of the SCNE reactor was 340-519\% higher than those of the conventional reactor, and the energy utilization to mineralize the equal weight of organic content was only $16.5-22.3 \%$ of the conventional reactor. The developed reactor has the potential for application in wastewater treatment [132]. The electrocoagulation is also useful for removing effluents from the polluted water [133]. These applications utilize the advantages of CNTs' properties such as high reactivity, strong adsorption, and high specific surface area [133-135]. Zhang et al. have fabricated Ti/ $\mathrm{SnO}_{2}-\mathrm{Sb}-\mathrm{CNTs}$ electrodes for anodic oxidation of dye-containing wastewater through the pulse electrodeposition method. The CNTs-modified electrode exhibited a larger surface area compared with that without CNTs, which provides a more active area for electrochemical oxidation of organic pollutants. The CNTs-modified electrode was 4.8 times more durable compared with that without CNTs. The modified electrode has a higher kinetic rate constant, chemical oxygen demand (COD), total organic carbon (TOC) removals, and current mineralization efficiency, which are 1.93, $1.27,1.26$, and 1.38 times higher, respectively, than those of the unmodified electrode. The CNTs-based electrode exhibited 1.15 times more permeation flux compared with the electrode without CNTs [136]. The electrochemically activated CNTs filters were developed for wastewater treatment [137]. Thus, 
the solutions for implementing water reuse, seawater desalination, and water purification more efficiently and cost-effectively are expected to emerge from the use of nanotechnology with CNTs. The applications of CNMs in wastewater treatment are also summarized in Table 7. It was noted that phenolic compounds are often explored in the commercial manufacturing of several products such as resins, polymeric materials, ion exchange resin, dyes, drugs, and explosives, among others. Owing to the extensive uses of phenolic products, a large amount of phenol is discharged from industries in the water, which causes toxicity and can damage the cellular proteins. Therefore, the removal of phenolic compounds from the contaminated water on a large scale is necessary for a healthy life. For this, CNTs with rich pore structure, analytic abilities, high surface area, and sharp curvatures show great potential for the removal of the phenolic compounds from the contaminated water through $\pi-\pi$, electrostatic, hydrophobic, and hydrogen bonding interactions [138]. Ma et al. have prepared CNTs/Fe@C hybrids material for the removal of the binary dye from the contaminated water through the one-pot method with a high specific surface area $\left(186.3 \mathrm{~m}^{2} / \mathrm{g}\right)$. A significant difference between single and binary dye systems was noted through the adsorption technique. The primary adsorption potentials of the prepared hybrids for the methylene blue (MB), methyl orange (MO), and neutral red (NR) were 132.58, 16.53 , and $98.81 \mathrm{mg} / \mathrm{g}$, respectively, and the adsorption equilibrium times were 80, 40, and $10 \mathrm{~min}$, respectively. The adsorption capacity and their changes in single and binary dye systems are given in Figure 9a. Cooperative adsorption was noted in the MB-MO dye system through the developed hybrids material. An enhancement in the adsorption capacity was observed in the MB-MO dye system by $30 \%$ and $35 \%$, with a decrease in the equilibrium time by $25 \%$ and $50 \%$. Meanwhile, the MB-NR dye system exhibited a competitive adsorption tendency. The adsorption isotherm of MO and MB from the prepared hybrids material is shown in Figure $9 \mathrm{~b}$. These results suggested that the prepared hybrids had the efficiency to be used as a promising adsorbent for the large-scale applications in binary dye systems, which exhibited a cooperative and competitive adsorption tendency to address the dye pollution effectively [139]. Lee and coworkers fabricated MWCNTs-based polyaniline (PANi)/polyether sulfone (PES) membranes by in situ polymerization of aniline in the presence of MWCNTs for the effective removal of natural organic matter (NOM) in water. The fabricated membranes exhibited 30 times greater efficiency than the PES membrane. This enhancement was attributed to the synergistic effects of the MWCNTs/PANi complex. The electrostatic interactions between the membrane surface and NOM facilitate the adsorption capacity of the developed membrane. The fabricated membrane exhibited $100 \%$ water flux recovery and $65 \%$ total fouling ratio after treatment with $0.1 \mathrm{M} \mathrm{HCl} / 0.1 \mathrm{M}$ $\mathrm{NaOH}$ solution for $1 \mathrm{~h}$ [140]. The extending exploration of SWCNTs raises environmental concerns. $\mathrm{Qu}$ et al. have evaluated the microbial communities' (Zoogloea, Rudaea, Mobilicocus, Burkholderia, Singulisphaera, Labrys, and Mucilaginibacter) responses of SWCNTs in phenol containing wastewater media. The enhancement in the phenol removal rates was observed in the SWCNTs-treated batch in 20 days initially. However, as the phenol concentrations increased to $1000 \mathrm{mg} / \mathrm{L}$ after 60 days, a decrease in the phenol removal rate was noted even at the higher concentration of SWCNTs $(3.5 \mathrm{~g} / \mathrm{L})$. It was noted that SWCNTs protected the microbes from inactivation by generating more bound extracellular polymeric substances (EPSs), which form a protective layer for the microbes. A significant decrease in the bacterial community structure was observed after the addition of SWCNTs. This phenomenon is associated with the change in sludge settling, aromatic degradation, and EPS generation. These results demonstrated that SWCNTs exhibited the protective response for sludge microbes in phenol containing wastewater media and enabled the important information related to the potential effects of SWCNTs on wastewater treatment processes [141]. 


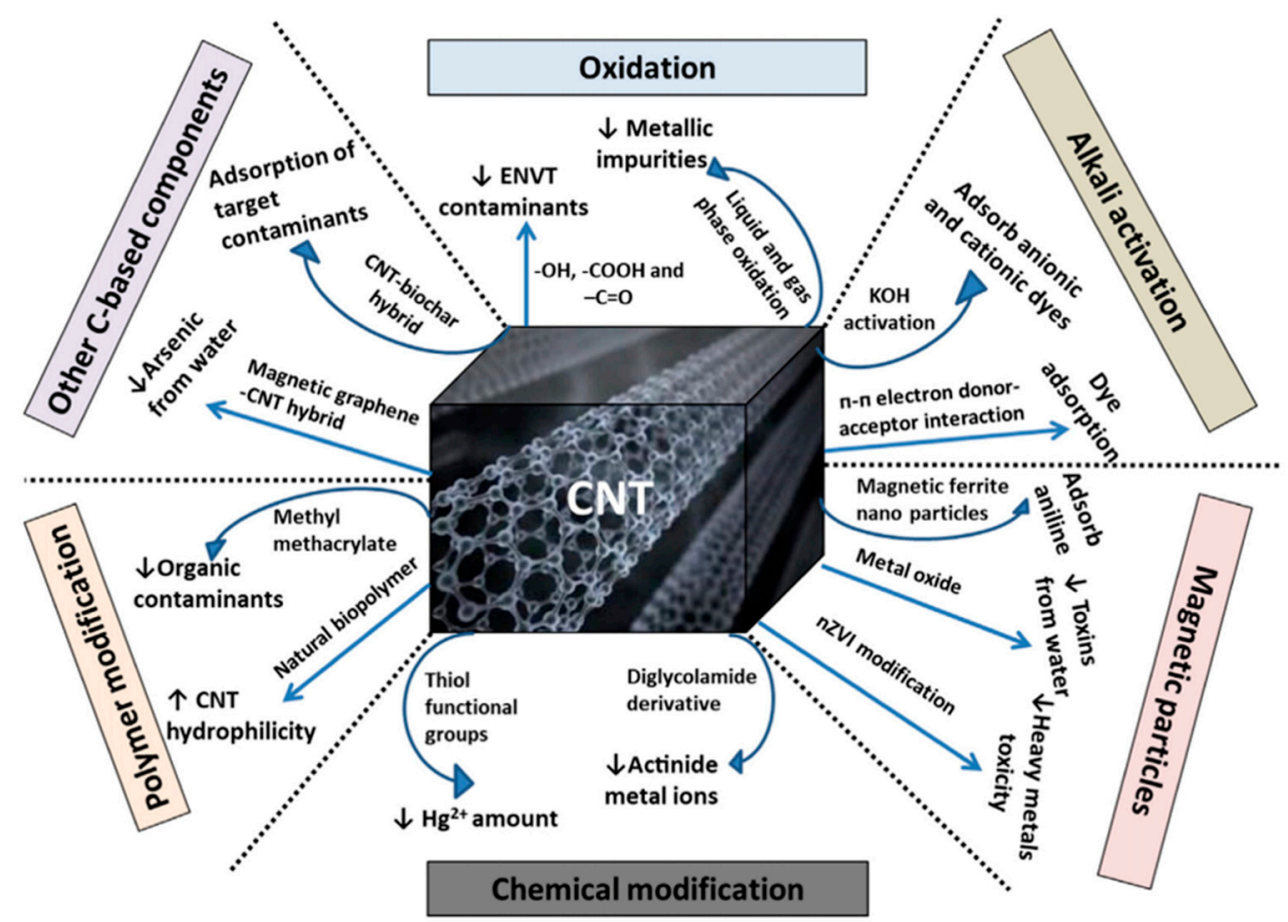

Figure 8. Schematic diagram representing different modification processes of CNTs for contaminant removal from water and wastewater (C: carbon; CNT: carbon nanotube; ENVT: environmental; Hg: mercury; KOH: potassium hydroxide) [129].

Table 7. Applications of CNMs in wastewater treatment. COD, chemical oxygen demand.

\begin{tabular}{|c|c|c|c|c|}
\hline Applications & $\begin{array}{c}\text { Desirable Nanomaterials } \\
\text { Properties }\end{array}$ & Type of CNMs & Efficiency of the CNMs & Reference \\
\hline \multirow[t]{2}{*}{ Catalysts } & $\begin{array}{l}\text { Higher catalyst loads and stability, } \\
\text { stronger metal-support }\end{array}$ & $\begin{array}{l}\text { Ruthenium/MWCNT- } \\
\text { COOH- } \mathrm{Na}_{2} \mathrm{CO}_{3}\end{array}$ & $\begin{array}{l}98.3 \% \text { and } 70.3 \% \text { aniline and } \\
\text { total organic carbon (TOC) } \\
\text { removals }\end{array}$ & [128] \\
\hline & $\begin{array}{l}\text { interactions, high dispersion, high } \\
\text { stability and activity, low cost }\end{array}$ & $\begin{array}{l}\text { Ruthenium/MWCNT- } \\
\text { COOH }\end{array}$ & $\begin{array}{l}89.9 \% \text { and } 53.7 \% \text { aniline and } \\
\text { TOC removals }\end{array}$ & [128] \\
\hline Mass Transfer & $\begin{array}{l}\text { Facilitate contaminant mass } \\
\text { transfer, large surface areas, high } \\
\text { electrochemical efficiency, } \\
\text { degrade organics with much } \\
\text { higher current Efficiency and } \\
\text { lower energy consumption }\end{array}$ & CNTs & $\begin{array}{l}\text { The efficiency was } 340-519 \% \\
\text { higher than the conventional } \\
\text { reactor, and the energy } \\
\text { consumption was only } \\
16.5-22.3 \% \text { of the } \\
\text { conventional reactor } \\
\text { The maximum zinc }\end{array}$ & [131] \\
\hline Adsorption & $\begin{array}{l}\text { Large specific surface areas, high } \\
\text { chemical and thermal stabilities, } \\
\text { high aspect ratios, exceptional } \\
\text { mechanical strength, diverse } \\
\text { contaminant-CNT interactions }\end{array}$ & SWCNTs, MWCNTs & $\begin{array}{c}\text { adsorption capacities of } \\
\text { SWCNTs and MWCNTs } \\
\text { were } 43.66 \text { and } 32.68 \mathrm{mg} / \mathrm{g} \text {, } \\
\text { respectively, in the initial } \\
\text { zinc ion concentration range } \\
\quad(10-80 \mathrm{mg} / \mathrm{L})\end{array}$ & [134] \\
\hline Flocculation & $\begin{array}{l}\text { Exceptional adsorption } \\
\text { capabilities and efficiencies, larger } \\
\text { surface area, affinity towards } \\
\text { target compounds }\end{array}$ & CNTs & $\begin{array}{l}\text { Demonstrated the ability to } \\
\text { successfully coagulate } \\
\text { colloidal particles in the } \\
\text { brewery wastewater }\end{array}$ & [135] \\
\hline Electrode & $\begin{array}{l}\text { Effective compound adsorption } \\
\text { and oxidation, high energy } \\
\text { efficiency, fast reaction rate, } \\
\text { electrochemical oxidation }\end{array}$ & $\begin{array}{l}\mathrm{Ti} / \mathrm{SnO}_{2}-\mathrm{Sb}-\mathrm{CNT} \\
\text { electrode }\end{array}$ & $\begin{array}{l}80.12 \% \text { and } 46.01 \% \text { COD and } \\
\text { TOC removals }\end{array}$ & [136] \\
\hline
\end{tabular}


(a)

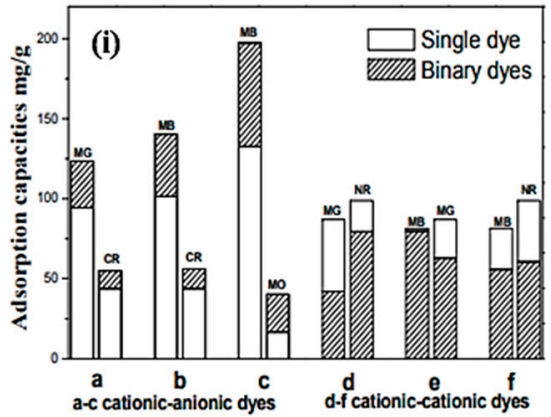

(b)
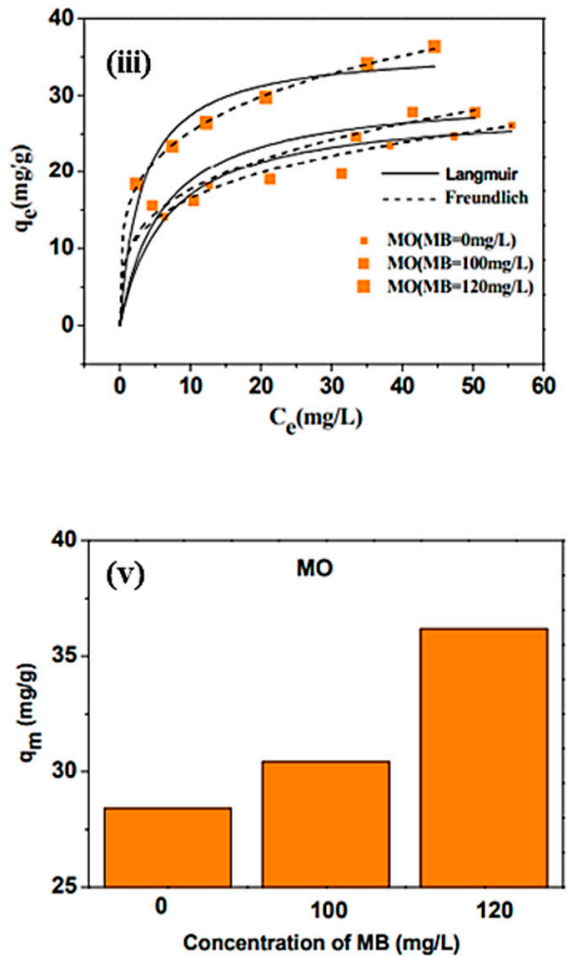
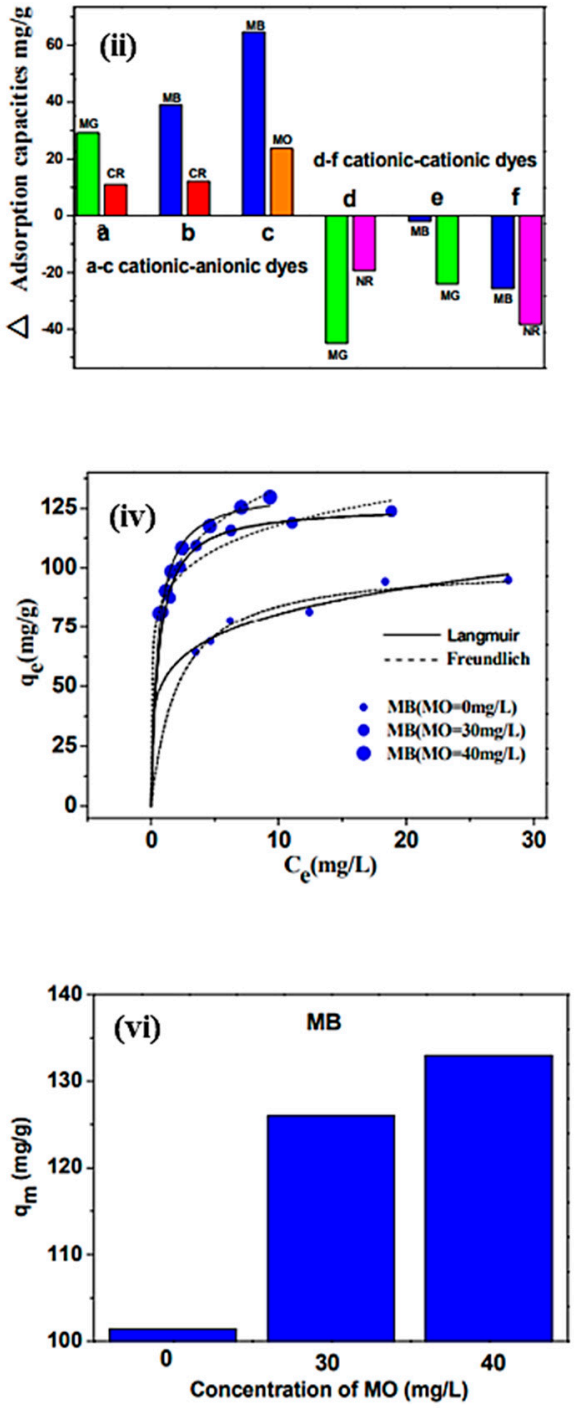

Figure 9. (a) (i) Adsorption capacities and (ii) their changes in single and binary dye systems. (b) Adsorption isotherms of methyl orange (MO) (iii) and methylene blue (MB) (iv) on CNTs/Fe@C fitted by the Langmuir and Freundlich models. The maximum adsorption capacity of MO (v) and MB

(vi) increased with the concentration of the other dye [139].

\subsubsection{Microbial Fuel Cells (MFCs)}

Microbial fuel cell (MFC) technology produces hydrogen or electrons by a bacterial oxidizing process from substances such as wastewater. This is the basic concept of generating electricity through an anode-cathode system. For this, the cathode should have excellent compatibility with microorganisms and possess a large specific surface area per unit volume, as well as excellent durability as chemically safety materials [142]. CNTs have received much attention for cathodic applications owing to their superior and tunable physiochemical potential. The electronic signal is also affected by the temperature of the medium [143]. The high limiting current density and electrochemical performance were observed in the deformed CNTs owing to the higher specific surface area generated by deformation [144]. The modification is required in CNMs to achieve the proper catalytic surface area for better electrochemical performance [145-147]. The change in the aspect ratio and surface area of CNTs was performed using a metal catalyst such as platinum $(\mathrm{Pt})$ [148-150]. The CNTs/Pt composites exhibited better powder density ( $\sim 8 \%$ higher) than the pure Pt catalyst when the chemical oxygen content of the substrate reached $100 \mathrm{mg} / \mathrm{L}$. The significant enhancement in the electrical properties 
was observed in nitrogen-doped CNTs [151]. The nitrogen-doped CNTs exhibited a maximum power density of $1600 \pm 50 \mathrm{~mW} \cdot \mathrm{m}^{-2}$, which is significantly higher than the commonly used Pt catalyst for cathode application. For a better reaction process, the surface area and durability of the anodic materials should be high $[152,153]$. The CNTs/polyaniline (PANi) composites showed an enhanced electrochemical activity at a higher content of CNTs in the medium [154]. The CNTs-coated anode demonstrated $\sim 62 \%$ higher voltage output than the untreated anode [155]. The performance of the anodic materials can also be improved by using the three-dimensional (3D) structure of graphene oxide (GO)/CNTs and melamine sponge composites [156]. The 3D graphene oxide (GO)/CNTs and melamine sponge display the highest electrochemical performance at a thickness of $1.5 \mathrm{~mm}$. The porous structure facilitates the biocompatibility of the composites. These results provide valuable insights into the active anode-cathode development for MFC applications. The effects of the carbon-based electrode on MFCs are also given in Table 8.

Table 8. The effects of the carbon-based electrode on microbial fuel cells (MFCs).

\begin{tabular}{|c|c|c|c|c|c|c|}
\hline \multicolumn{2}{|c|}{ Type of Electrode } & \multirow{2}{*}{ MFCs } & \multirow{2}{*}{ Type of MFCs } & \multirow{2}{*}{ Effect } & \multirow{2}{*}{$\begin{array}{l}\text { Power Density } \\
\text { (Max.) } \mathrm{mW} / \mathrm{m}\end{array}$} & \multirow{2}{*}{ Reference } \\
\hline Anode & Cathode & & & & & \\
\hline Graphite fiber & $\begin{array}{c}\text { Carbon } \\
\text { nanotube/Pt }\end{array}$ & $\begin{array}{l}\text { Effluent from an } \\
\text { air-cathode MFC }\end{array}$ & Single chamber MFCs & $\begin{array}{l}\text { The cathode had a maximum } \\
\text { power density of about two } \\
\text { times higher than that of the } \\
\text { carbon cloth cathode }\end{array}$ & 329 & [144] \\
\hline Carbon paper & CNTs/Poly-pyrrole & $\begin{array}{c}\text { Anaerobic digester } \\
\text { sludge collected from } \\
\text { Indah Water } \\
\text { Konsortium treated } \\
\text { Palm oil mill effluent } \\
\text { (POME) }\end{array}$ & $\begin{array}{l}\text { Two cubic shaped } \\
\text { chambers }\end{array}$ & $\begin{array}{l}\text { COD removal of the system } \\
\text { using CNT/PPy was } 96 \%\end{array}$ & 113.5 & [145] \\
\hline Carbon cloth & $\begin{array}{l}\mathrm{N}-\mathrm{CNTs} \text { on carbon } \\
\text { cloth }\end{array}$ & $\begin{array}{c}\text { Acetate-laden } \\
\text { synthetic wastewater }\end{array}$ & $\begin{array}{l}\text { Air-cathode } \\
\text { cylindrical-shaped } \\
\text { MFCs, dual chamber }\end{array}$ & $\begin{array}{l}\text { The maximum power density } \\
\text { was about } 9 \% \text { higher than that } \\
\text { of Pt-carbon on carbon cloth }\end{array}$ & 135 & [147] \\
\hline Carbon paper & $\mathrm{CNTs} / \mathrm{Pt}$ & $\begin{array}{l}\text { Palm oil mill effluent } \\
\text { (POME- Selangor, } \\
\text { Malaysia) sludge }\end{array}$ & $\begin{array}{l}\text { Two cylindrical } \\
\text { H-shaped chambers }\end{array}$ & $\begin{array}{l}\text { The composite electrode } \\
\text { increased the power output of } \\
\text { MFC by } 8.7 \sim 32 \% \text { compared } \\
\text { with Pt electrode }\end{array}$ & 169.7 & [149] \\
\hline Carbon paper & $\begin{array}{l}\text { Chemically } \\
\text { activated carbon } \\
\text { nanofibers }\end{array}$ & $\begin{array}{l}\text { Palm oil mill effluent } \\
\text { (POME) anaerobic } \\
\text { (Selangor, Malaysia) } \\
\text { sludge }\end{array}$ & $\begin{array}{l}\text { Two cylindrical and } \\
\text { H-shaped chambers }\end{array}$ & $\begin{array}{l}\text { COD removal was } \\
\text { approximately } 82.3 \% \text { and could } \\
\text { generate up to } 3.17 \text { times more } \\
\text { power than carbon paper }\end{array}$ & 61.3 & [150] \\
\hline Carbon fiber & $\begin{array}{l}\text { Nitrogen-doped } \\
\text { CNTs (N-CNTs) }\end{array}$ & $\begin{array}{c}20 \% \text { domestic } \\
\text { wastewater collected } \\
\text { from a municipal } \\
\text { wastewater treatment } \\
\text { plant of Shanghai, } \\
\text { China }\end{array}$ & $\begin{array}{l}\text { Air-cathode single } \\
\text { chamber MFCs }\end{array}$ & $\begin{array}{l}\text { The power density drop rate } \\
\text { was low, so electricity can be } \\
\text { produced more permanently } \\
\text { than the platinum catalyst }\end{array}$ & $1600 \pm 50$ & [151] \\
\hline $\begin{array}{l}\text { MWCNT/ } \\
\text { rGO-biofilm }\end{array}$ & carbon fiber brush & $\begin{array}{l}\text { S. putrefaciens CN32 } \\
\text { cell suspension was } \\
\text { inoculated on bacteria }\end{array}$ & H-type dual-chamber & $\begin{array}{l}\text { Composite electrodes provide } \\
\text { higher maximum power } \\
\text { density than individual } \\
\text { MWCNTs and rGO }\end{array}$ & 789 & [152] \\
\hline $\begin{array}{c}\text { Vertically } \\
\text { Aligned CNTs }\end{array}$ & $\mathrm{Cr} / \mathrm{Au}$ film & \multirow{3}{*}{\multicolumn{2}{|c|}{$\begin{array}{c}\text { Acetate-fed microbial electrolytic cells (MEC) } \\
\text { with Geobacter-enriched bacterial community } \\
\text { from anaerobic digestion sludge } \\
\text { Dual chamber MFCs; anode and cathode } \\
\text { chambers }\end{array}$}} & $61.3 \%$ of Coulombic efficiency & 270 & [153] \\
\hline $\begin{array}{l}\text { Randomly } \\
\text { Aligned CNTs } \\
\text { Spin/spray }\end{array}$ & $\mathrm{Cr} / \mathrm{Au}$ film & & & $73 \%$ of Coulombic efficiency & 540 & \\
\hline $\begin{array}{l}\text { layer-by-layer } \\
\text { CNTs }\end{array}$ & $\mathrm{Cr} / \mathrm{Au}$ film & & & $73 \%$ of Coulombic efficiency & 540 & \\
\hline $\begin{array}{l}\text { CNTs/polyaniline } \\
\text { (PANI) }\end{array}$ & $\mathrm{Pt}$ & Bacteria & E. coli-based MFCs & $\begin{array}{c}\text { Composite electrodes } \\
\text { containing } 20 \mathrm{wt} . \% \mathrm{CNTs} \\
\text { provide high discharge } \\
\text { performance and high power } \\
\text { output }\end{array}$ & 42 & [154] \\
\hline CNTs & $\mathrm{CNTs} / \mathrm{Pt}$ & Bacteria & Air-cathode MFCs & $\begin{array}{l}\text { COD removal was } 95 \% \text { and the } \\
\text { maximum coulombic efficiency } \\
\text { was } 67 \%\end{array}$ & 65 & [155] \\
\hline $\begin{array}{l}\text { rGO-CNT } \\
\text { sponges }\end{array}$ & - & Anaerobic sludge & $\begin{array}{l}\text { Aerobic chamber and } \\
\text { anoxic chamber }\end{array}$ & Produced higher durability & $\begin{array}{l}\text { Max. current } \\
\text { density of } 335 \mathrm{~A} \\
\mathrm{~m}^{-3}\end{array}$ & [156] \\
\hline
\end{tabular}

\subsubsection{High-Efficiency Electrical Devices}

For energy applications, it is crucial to increase the energy density of the material without compromising other electrochemical properties [157]. CNTs are not only light in weight, but also have a sufficient area for hydrogen storing in their tubular structure, which can increase the charge storage capacity per unit mass [158-166]. CNTs can also be utilized in other electrochemical 
applications [167,168] and supercapacitor preparation [169-172]. An increased surface area of CNMs is required for energy applications with pore sizes of 0.7 to $0.9 \mathrm{~nm}$, which are suitable for the ions approach. It has been proved that hydrogen is stored in the pores formed in the space between the tubes, and the adsorbed hydrogen molecules are subjected to a stable surface suction force. Approximately $3.3 \mathrm{wt} . \%$ and $0.7 \mathrm{wt} . \%$ hydrogen adsorption was noted within the tube $(10,10)$ and interstitial space of CNTs, respectively [160]. A hierarchical structure is required to obtain the high output characteristics, which are connected in a vast pore region for the fast ion diffusion even at a high current density. The maximum power density can also be improved by using the cetrimonium bromide (CTAB) with CNTs [173]. A porous three-dimensional structure was formed by intercalating the CNTs into graphite in a vertical direction to improve the maximum energy density. A significant enhancement in the maximum energy density was observed in this structure, which was $117.2 \mathrm{Wh} / \mathrm{L}$ at a maximum power density of $424 \mathrm{~kW} / \mathrm{L}$ per volume, and a maximum energy density of $110.6 \mathrm{Wh} / \mathrm{kg}$ at a maximum power density of $400 \mathrm{~kW} / \mathrm{kg}$ per weight. This kind of structure is light in weight, which provides additional advantages to make small portable electronic products such as automobile batteries, rechargeable batteries, and notebook computers. The hydrogen storage capacity of different types of CNTs is given in Table 9. The hydrogen storage ability of CNTs is shown in Figure 10. The interaction energy plays a vital role in the storage of hydrogen. The results indicated that CNTs could effectively store hydrogen under cryogenic conditions, which is not suitable for mobile applications. This is because of the reduced interaction energy $(1 \mathrm{kcal} / \mathrm{mol})$ between hydrogen and the CNTs. For significant, but reversible storage under ambient conditions, the interaction energies should be around $7 \mathrm{kcal} / \mathrm{mol}$. The interaction energy can be tuned by doping with heteroatoms or by incorporating light metal ions in CNTs [174].

Table 9. Hydrogen storage efficiency of different kinds of CNMs at different conditions.

\begin{tabular}{ccccc}
\hline CNMs & Storage (wt.\%) & Temperature (K) & Pressure (MPa) & Reference \\
\hline CNTs & 9.6 & 77 & 10 & {$[159]$} \\
CNTs & 1.5 & 296 & 12.5 & {$[160]$} \\
SWCNTs & 4.5 & 77 & 6 & {$[161]$} \\
Chemically activated carbon & 5.6 & 77 & 4 & {$[162]$} \\
Carbon with boron & 5.9 & 298 & 10 & {$[163]$} \\
SWCNTs & 1.73 & 77 & 10 & {$[164]$} \\
SWCNTs-SnO & 2.4 & 623 & 5 & {$[165]$} \\
Si-doped SWCNTs & 2.5 & 298 & 10 & {$[166]$} \\
Un-doped SWCNTs & 1.4 & 298 & 10 & \\
\hline
\end{tabular}
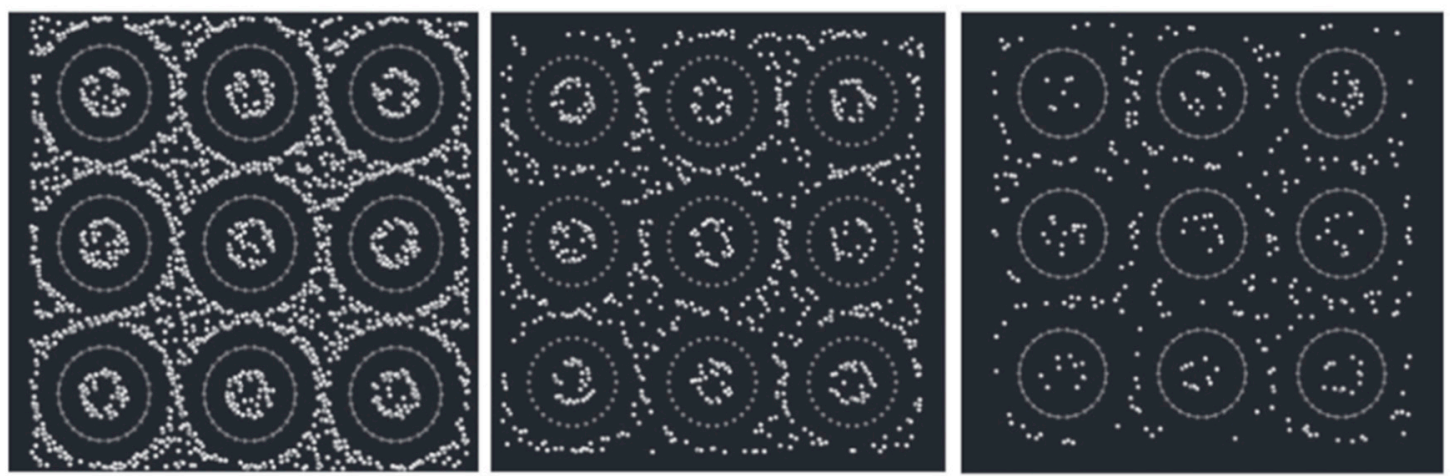

Figure 10. Hydrogen storage in nanotube bundles. Snapshots from grand canonical Monte Carlo simulations taken under 100 Bar pressure at $77 \mathrm{~K}$ (left), $175 \mathrm{~K}$ (middle), and $293 \mathrm{~K}$ (right) [173]. 


\section{Conclusions}

CNTs have received a significant amount of interest in various applications owing to their superior physiochemical properties. Notably, the physicochemical properties of CNTs are profoundly affected by the diameter and helicity of the graphene sheet, as well as the number of graphene layers. The significant enhancement in the seeds germination/plant growth was noted in the presence of carbon-based nanomaterials compared with the control owing to the penetration of the seed coat, which allows more water uptake. However, the exact mechanism of action is still unclear. The CNTs-based sensor exhibited high sensitivity and stability, fast response time, and excellent luminescence properties. The high adsorption potential of CNTs facilitates the extraction process and is widely explored in the extraction technique for the removal of contaminants from the samples. CNTs or their derivatives are often utilized in the nanotechnology sector to develop high-efficient battery, fuel cells, electrode reactor for wastewater treatment, and energy storage. Notably, better electrochemical performances were observed in CNTs-based electrode compared with the control. CNTs can store hydrogen molecules in their structure, and this potential can be tuned by changing the electronic environment of CNTs.

Funding: This research was supported by the 'Basic Research Program' through the 'National Research Foundation of Korea (NRF)' funded by the 'Ministry of Education' (NRF-2018R1A6A1A03025582 \& NRF-2019R1D1A3A03103828).

Conflicts of Interest: The authors declare no conflict of interest.

\section{References}

1. Harrison, B.S.; Atala, A. Carbon nanotube applications for tissue engineering. Biomaterials 2007, 28, 344-353. [CrossRef]

2. He, H.; Pham-Huy, L.; Dramou, P.; Xiao, D.; Zuo, P.; Pham-Huy, C. Carbon Nanotubes: Applications in pharmacy and medicine. BioMed Res. Int. 2013, 2013, 1-12. [CrossRef] [PubMed]

3. Salvetat, J.P.; Bonard, J.M.; Thomson, N.; Kulik, A.; Forro, L.; Benoit, W.; Zuppiroli, L. Mechanical properties of carbon nanotubes. Appl. Phys. A 1999, 69, 255-260. [CrossRef]

4. Odom, T.W.; Huang, J.-L.; Kim, P.; Lieber, C.M. Atomic structure and electronic properties of single-walled carbon nanotubes. Nature 1998, 391, 62-64. [CrossRef]

5. Ruoff, R.S.; Lorents, D.C. Mechanical and thermal properties of carbon nanotubes. Carbon 1995, 33, 925-930. [CrossRef]

6. Veetil, J.V.; Ye, K. Tailored carbon nanotubes for tissue engineering applications. Biotechnol. Prog. 2009, 25, 709-721. [CrossRef] [PubMed]

7. Ravindran, S.; Chaudhary, S.; Colburn, B.; Ozkan, M.; Ozkan, C.S. Covalent coupling of quantum dots to multiwalled carbon nanotubes for electronic device applications. Nano Lett. 2003, 3, 447-453. [CrossRef]

8. Wang, Q.H.; Yan, M.; Chang, R.P. Flat panel display prototype using gated carbon nanotube field emitters. Appl. Phys. Lett. 2001, 78, 1294-1296. [CrossRef]

9. Bachtold, A.; Hadley, P.; Nakanishi, T.; Dekker, C. Logic circuits with carbon nanotube transistors. Science 2001, 294, 1317-1320. [CrossRef]

10. Martel, R.; Schmidt, T.; Shea, H.; Hertel, T.; Avouris, P. Single-and multi-wall carbon nanotube field-effect transistors. Appl. Phys. Lett. 1998, 73, 2447-2449. [CrossRef]

11. Kuche, K.; Maheshwari, R.; Tambe, V.; Mak, K.; Jogi, H.; Raval, N.; Pichika, M.; Kumar Tekade, R. Carbon nanotubes (CNTs) based advanced dermal therapeutics: Current trends and future potential. Nanoscale 2018, 10, 8911-8937. [CrossRef] [PubMed]

12. Lahiani, M.; Nima, Z.; Villagarcia, H.; Biris, A.S.; Khodakovskaya, M. Assessment of effects of the long-term exposure of agricultural crops to carbon nanotubes. J. Agric. Food Chem. 2018, 66, 6654-6662. [CrossRef] [PubMed]

13. Wang, Y.; Chang, C.; Ji, Z.; Bouchard, D.C.; Nisbet, R.M.; Schimel, J.P.; Holden, P. Agglomeration determines effects of carbonaceous nanomaterials on soybean nodulation, dinitrogen fixation potential, and growth in Soil. ACS Nano 2017, 11, 5753-5765. [CrossRef] [PubMed] 
14. Ge, Y.; Shen, C.; Wang, Y.; Sun, Y.; Schimel, J.; Gardea-Torresdey, J.; Holden, P. Carbonaceous nanomaterials have higher effects on soybean Rhizosphere prokaryotic communities during therReproductive growth phase than during vegetative growth. Environ. Sci. Technol. 2018, 52, 6636-6646. [CrossRef]

15. Wong, B.S.; Yoong, S.L.; Jagusiak, A.; Panczyk, T.; Ho, H.K.; Ang, W.H.; Pastorin, G. Carbon nanotubes for delivery of small molecule drugs. Adv. Drug Deliv. Rev. 2013, 65, 1964-2015. [CrossRef]

16. Hopley, E.L.; Salmasi, S.; Kalaskar, D.M.; Seifalian, A.M. Carbon nanotubes leading the way forward in new generation 3D tissue engineering. Biotechnol. Adv. 2014, 32, 1000-1014. [CrossRef]

17. Gholizadeh, S.; Moztarzadeh, F.; Haghighipour, N.; Ghazizadeh, L.; Baghbani, F.; Shokrgozar, M.A.; Allahyari, Z. Preparation and characterization of novel functionalized multiwalled carbon nanotubes/chitosan / $\beta$-Glycerophosphate scaffolds for bone tissue engineering. Int. J. Biol. Macromol. 2017, 97, 365-372. [CrossRef]

18. Iijima, S. Helical microtubules of graphitic carbon. Nature 1991, 354, 56-58. [CrossRef]

19. Kim, H.H.; Kim, H.J. The preparation of carbon nanotubes by dc arc discharge using a carbon cathode coated with catalyst. Mater. Sci. Eng. B 2006, 130, 73-80. [CrossRef]

20. Cui, S.; Scharff, P.; Siegmund, C.; Schneider, D.; Risch, K.; Klötzer, S.; Spiess, S.; Romanus, H.; Schawohl, J. Investigation on preparation of multiwalled carbon nanotubes by DC arc discharge under N 2 atmosphere. Carbon 2004, 42, 931-939. [CrossRef]

21. Lange, H.; Sioda, M.; Huczko, A.; Zhu, Y.; Kroto, H.; Walton, D. Nanocarbon production by arc discharge in water. Carbon 2003, 41, 1617-1623. [CrossRef]

22. Guo, T.; Nikolaev, P.; Thess, A.; Colbert, D.; Smalley, R. Catalytic growth of single-walled manotubes by laser vaporization. Chem. Phys. Lett. 1995, 243, 49-54. [CrossRef]

23. Rinzler, A.; Liu, J.; Dai, H.; Nikolaev, P.; Huffman, C.; Rodriguez-Macias, F.; Boul, P.J.; Lu, A.H.; Heymann, D.; Colbert, D.T.; et al. Large-scale purification of single-wall carbon nanotubes: Process, product, and characterization. Appl. Phys. A Mater. Sci. Process. 1998, 67, 29-37. [CrossRef]

24. Lebedkin, S.; Schweiss, P.; Renker, B.; Malik, S.; Hennrich, F.; Neumaier, M.; Stoermer, C.; Kappes, M.M. Single-wall carbon nanotubes with diameters approaching $6 \mathrm{~nm}$ obtained by laser vaporization. Carbon 2002, 40, 417-423. [CrossRef]

25. Jost, O.; Gorbunov, A.; Pompe, W.; Pichler, T.; Friedlein, R.; Knupfer, M.; Reibold, M.; Bauer, H.D.; Dunsch, L.; Golden, M.S.; et al. Diameter grouping in bulk samples of single-walled carbon nanotubes from optical absorption spectroscopy. Appl. Phys. Lett. 1999, 75, 2217-2219. [CrossRef]

26. Kong, J.; Cassell, A.M.; Dai, H. Chemical vapor deposition of methane for single-walled carbon nanotubes. Chem. Phys. Lett. 1998, 292, 567-574. [CrossRef]

27. Cassell, A.M.; Raymakers, J.A.; Kong, J.; Dai, H. Large scale CVD synthesis of single-walled carbon nanotubes. J. Phys. Chem. B 1999, 103, 6484-6492. [CrossRef]

28. Lee, C.J.; Park, J. Growth model of bamboo-shaped carbon nanotubes by thermal chemical vapor deposition. Appl. Phys. Lett. 2000, 77, 3397-3399. [CrossRef]

29. Lee, C.J.; Park, J.; Huh, Y.; Lee, J.Y. Temperature effect on the growth of carbon nanotubes using thermal chemical vapor deposition. Chem. Phys. Lett. 2001, 343, 33-38. [CrossRef]

30. Lee, C.J.; Park, J.; Jeong, A.Y. Catalyst effect on carbon nanotubes synthesized by thermal chemical vapor deposition. Chem. Phys. Lett. 2002, 360, 250-255. [CrossRef]

31. Chhowalla, M.; Teo, K.; Ducati, C.; Rupesinghe, N.; Amaratunga, G.; Ferrari, A.; Roy, D.; Robertson, J.; Milne, W.I. Growth process conditions of vertically aligned carbon nanotubes using plasma enhanced chemical vapor deposition. J. Appl. Phys. 2001, 90, 5308-5317. [CrossRef]

32. Bower, C.; Zhou, O.; Zhu, W.; Werder, D.; Jin, S. Nucleation and growth of carbon nanotubes by microwave plasma chemical vapor deposition. Appl. Phys. Lett. 2000, 77, 2767-2769. [CrossRef]

33. Qin, L.; Zhou, D.; Krauss, A.; Gruen, D. Growing carbon nanotubes by microwave plasma-enhanced chemical vapor deposition. Appl. Phys. Lett. 1998, 72, 3437-3439. [CrossRef]

34. Hofmann, S.; Ducati, C.; Robertson, J.; Kleinsorge, B. Low-temperature growth of carbon nanotubes by plasma-enhanced chemical vapor deposition. Appl. Phys. Lett. 2003, 83, 135-137. [CrossRef]

35. Lee, C.J.; Lyu, S.C.; Kim, H.-W.; Park, C.-Y.; Yang, C.-W. Large-scale production of aligned carbon nanotubes by the vapor phase growth method. Chem. Phys. Lett. 2002, 359, 109-114. [CrossRef]

36. Yang, K.; Gu, M.; Guo, Y.; Pan, X.; Mu, G. Effects of carbon nanotube functionalization on the mechanical and thermal properties of epoxy composites. Carbon 2009, 47, 1723-1737. [CrossRef] 
37. Gulotty, R.; Castellino, M.; Jagdale, P.; Tagliaferro, A.; Balandin, A.A. Effects of functionalization on thermal properties of single-wall and multi-wall carbon nanotube-polymer nanocomposites. ACS Nano 2013, 7, 5114-5121. [CrossRef]

38. Arora, N.; Sharma, N. Arc discharge synthesis of carbon nanotubes: Comprehensive review. Diam. Relat. Mater. 2014, 50, 135-150. [CrossRef]

39. Ma, L.; Hart, A.; Ozden, S.; Vajtai, R.; Ajayan, P. Spiers memorial lecture: Advances of carbon nanomaterials. Faraday Discuss 2014, 173, 9-46. [CrossRef]

40. Odom, T.W.; Huang, J.-L.; Kim, P.; Lieber, C.M. Structure and electronic properties of carbon nanotubes. J. Phys. Chem. B 2000, 104, 2794-2809. [CrossRef]

41. Saifuddin, N.; Raziah, A.; Junizah, A. Carbon nanotubes: A review on structure and their interaction with proteins. J. Chem. 2013, 2013, 1-18. [CrossRef]

42. Charlier, J.-C.; Issi, J.-P. Electronic structure and quantum transport in carbon nanotubes. Appl. Phys. A Mater. Sci. Process. 1998, 67, 79-87. [CrossRef]

43. Sanvito, S.; Kwon, Y.-K.; Tománek, D.; Lambert, C.J. Fractional quantum conductance in carbon nanotubes. Phys. Rev. Lett. 2000, 84, 1974. [CrossRef] [PubMed]

44. Kim, Y.J.; Shin, T.S.; Do Choi, H.; Kwon, J.H.; Chung, Y.-C.; Yoon, H.G. Electrical conductivity of chemically modified multiwalled carbon nanotube/epoxy composites. Carbon 2005, 43, 23-30. [CrossRef]

45. Ram, R.; Rahaman, M.; Khastgir, D. Electrical properties of polyvinylidene fluoride (PVDF)/multi-walled carbon nanotube (MWCNT) semi-transparent composites: Modelling of DC conductivity. Compos. Part A Appl. Sci. Manuf. 2015, 69, 30-39. [CrossRef]

46. Thess, A.; Lee, R.; Nikolaev, P.; Dai, H. Crystalline ropes of metallic carbon nanotubes. Science 1996, $273,483$. [CrossRef]

47. Kymakis, E.; Alexandou, I.; Amaratunga, G. Single-walled carbon nanotube-polymer composites: Electrical, optical and structural investigation. Synth. Met. 2002, 127, 59-62. [CrossRef]

48. Ruoff, R.S.; Qian, D.; Liu, W.K. Mechanical properties of carbon nanotubes: Theoretical predictions and experimental measurements. C. R. Phys. 2003, 4, 993-1008. [CrossRef]

49. Wei, L.; Kuo, P.; Thomas, R.; Anthony, T.; Banholzer, W. Thermal conductivity of isotopically modified single crystal diamond. Phys. Rev. Lett. 1993, 70, 3764. [CrossRef]

50. Hone, J.; Whitney, M.; Piskoti, C.; Zettl, A. Thermal conductivity of single-walled carbon nanotubes. Phys. Rev. B 1999, 59, R2514. [CrossRef]

51. Kim, P.; Shi, L.; Majumdar, A.; McEuen, P. Thermal transport measurements of individual multiwalled nanotubes. Phys. Rev. Lett. 2001, 87, 215502. [CrossRef] [PubMed]

52. Navarro-Pardo, F.; Martinez-Hernandez, A.L.; Velasco-Santos, C. Carbon nanotube and graphene based polyamide electrospun nanocomposites: A review. J. Nanomater. 2016, 2016, 1-16. [CrossRef]

53. Jackson, E.M.; Laibinis, P.E.; Collins, W.E.; Ueda, A.; Wingard, C.D.; Penn, B. Development and thermal properties of carbon nanotube-polymer composites. Compos. Part B Eng. 2016, 89, 362-373. [CrossRef]

54. Treacy, M.J.; Ebbesen, T.; Gibson, J. Exceptionally high Young's modulus observed for individual carbon nanotubes. Nature 1996, 381, 678-680. [CrossRef]

55. Krishnan, A.; Dujardin, E.; Ebbesen, T.; Yianilos, P.; Treacy, M. Young's modulus of single-walled nanotubes. Phys. Rev. B 1998, 58, 14013. [CrossRef]

56. Sánchez-Portal, D.; Artacho, E.; Soler, J.M.; Rubio, A.; Ordejón, P. Ab initio structural, elastic, and vibrational properties of carbon nanotubes. Phys. Rev. B 1999, 59, 12678. [CrossRef]

57. Goze, C.; Vaccarini, L.; Henrard, L.; Bernier, P.; Hemandez, E.; Rubio, A. Elastic and mechanical properties of carbon nanotubes. Synth. Met. 1999, 103, 2500-2501. [CrossRef]

58. Chatterjee, S.; Nafezarefi, F.; Tai, N.; Schlagenhauf, L.; Nüesch, F.; Chu, B. Size and synergy effects of nanofiller hybrids including graphene nanoplatelets and carbon nanotubes in mechanical properties of epoxy composites. Carbon 2012, 50, 5380-5386. [CrossRef]

59. Jiang, Q.; Wang, X.; Zhu, Y.; Hui, D.; Qiu, Y. Mechanical, electrical and thermal properties of aligned carbon nanotube/polyimide composites. Compos. Part B Eng. 2014, 56, 408-412. [CrossRef]

60. Lin, D.; Xing, B. Phytotoxicity of nanoparticles: Inhibition of seed germination and root growth. Environ. Pollut. 2007, 150, 243-250. [CrossRef]

61. Zaytseva, O.; Neumann, G. Carbon nanomaterials: Production, impact on plant development, agricultural and environmental applications. Chem. Biol. Technol. Agric. 2016, 3, 17. [CrossRef] 
62. Juganson, K.; Ivask, A.; Blinova, I.; Mortimer, M.; Kahru, A. NanoE-Tox: New and in-depth database concerning ecotoxicity of nanomaterials. Beilstein J. Nanotechnol. 2015, 6, 1788-1804. [CrossRef] [PubMed]

63. Khodakovskaya, M.; Dervishi, E.; Mahmood, M.; Xu, Y.; Li, Z.; Watanabe, F.; Biris, A.S. Carbon nanotubes are able to penetrate plant seed coat and dramatically affect seed germination and plant growth. ACS Nano 2009, 3, 3221-3227. [CrossRef] [PubMed]

64. Mondal, A.; Basu, R.; Das, S.; Nandy, P. Beneficial role of carbon nanotubes on mustard plant growth: An agricultural prospect. J. Nanopart. Res. 2011, 3, 4519-4528. [CrossRef]

65. Ratnikova, T.A.; Podila, R.; Rao, A.M.; Taylor, A.G. Tomato seed coat permeability to selected carbon nanomaterials and enhancement of germination and seedling growth. Sci. World J. 2015, 2015, 1-9. [CrossRef]

66. Lahiani, M.H.; Chen, J.; Irin, F.; Puretzky, A.A.; Green, M.J.; Khodakovskaya, M.V. Interaction of carbon nanohorns with plants: Uptake and biological effects. Carbon 2015, 81, 607-619. [CrossRef]

67. Martínez-Ballesta, M.C.; Zapata, L.; Chalbi, N.; Carvajal, M. Multiwalled carbon nanotubes enter broccoli cells enhancing growth and water uptake of plants exposed to salinity. J. Nanobiotechnol. 2016, 14, 42-56. [CrossRef]

68. Lahiani, M.H.; Dervishi, E.; Chen, J.; Nima, Z.; Gaume, A.; Biris, A.S.; Khodakovskaya, M.V. Impact of carbon nanotube exposure to seeds of valuable crops. ACS Appl. Mater. Interfaces 2013, 5, 7965-7973. [CrossRef]

69. Khodakovskaya, M.V.; Kim, B.S.; Kim, J.N.; Alimohammadi, M.; Dervishi, E.; Mustafa, T.; Cernigla, C.E. Carbon nanotubes as plant growth regulators: Effects on tomato growth, reproductive system, and soil microbial community. Small 2013, 9, 115-123. [CrossRef]

70. Jiang, Y.; Hua, Z.; Zhao, Y.; Liu, Q.; Wang, F.; Zhang, Q. The effect of carbon nanotubes on rice seed germination and root growth. In Proceedings of the 2012 International Conference on Applied Biotechnology (ICAB 2012); Springer-Nature: Berlin, Germany, 2014; pp. 1207-1212.

71. Cañas, J.E.; Long, M.; Nations, S.; Vadan, R.; Dai, L.; Luo, M.; Ambikapathi, E.; Lee, E.H.; Olszyk, D. Effects of functionalized and nonfunctionalized single walled carbon nanotubes on root elongation of select crop species. Environ. Toxicol. Chem. 2008, 27, 1922-1931. [CrossRef]

72. Deng, Y. Uptake and Accumulation of Engineered Nanomaterials by Agricultural Crops and Associated Risks in the Environment and Food Safety. Ph.D. Thesis, UMass Amherst, Amherst, MA, USA, September 2006.

73. Chang, X.; Song, Z.; Xu, Y.; Gao, M. Effects of carbon nanotubes on growth of wheat seedlings and Cd uptake. Chemosphere 2020, 240, 124931-124941. [CrossRef] [PubMed]

74. Cano, A.M.; Kohl, K.; Deleon, S.; Payton, P.; Irin, F.; Saed, M.; Shah, S.A.; Green, M.J.; Canas-Carrel, J.E. Determination of uptake, accumulation, and stress effects in corn (Zea mays L.) grown in single-wall carbon nanotube contaminated soil. Chemosphere 2016, 152, 117-122. [CrossRef] [PubMed]

75. Pandey, K.; Lahiani, M.; Hicks, V.; Hudson, M.; Green, M.; Khodakovskaya, M. Effects of carbon-based nanomaterials on seed germination, biomass accumulation and salt stress response of bioenergy crops. PLoS ONE 2018, 13, e0202274. [CrossRef]

76. Leonard, P.; Hearty, S.; Brennan, J.; Dunne, L.; Quinn, J.; Chakraborty, T.; O'Kennedy, R. Advances in biosensors for detection of pathogens in food and water. Enzym. Microb. Technol. 2003, 32, 3-13. [CrossRef]

77. Ivnitski, D.; Abdel-Hamid, I.; Atanasov, P.; Wilkins, E. Biosensors for detection of pathogenic bacteria. Biosens. Bioelectron. 1999, 14, 599-624. [CrossRef]

78. Yang, N.; Chen, X.; Ren, T.; Zhang, P.; Yang, D. Carbon nanotube based biosensors. Sens. Actuators B Chem. 2015, 207, 690-715. [CrossRef]

79. Baruah, S.; Dutta, J. Nanotechnology applications in pollution sensing and degradation in agriculture: A review. Environ. Chem. Lett. 2009, 7, 191-204. [CrossRef]

80. Sanvicens, N.; Pastells, C.; Pascual, N.; Marco, M.-P. Nanoparticle-based biosensors for detection of pathogenic bacteria. TrAC Trends Anal. Chem. 2009, 28, 1243-1252. [CrossRef]

81. Simonian, A.; Good, T.; Wang, S.-S.; Wild, J. Nanoparticle-based optical biosensors for the direct detection of organophosphate chemical warfare agents and pesticides. Anal. Chim. Acta 2005, 534, 69-77. [CrossRef]

82. Nam, J.-M.; Thaxton, C.S.; Mirkin, C.A. Nanoparticle-based bio-bar codes for the ultrasensitive detection of proteins. Science 2003, 301, 1884-1886. [CrossRef]

83. Kruss, S.; Hilmer, A.J.; Zhang, J.; Reuel, N.F.; Mu, B.; Strano, M.S. Carbon nanotubes as optical biomedical sensors. Adv. Drug Deliv. Rev. 2013, 65, 1933-1950. [CrossRef] [PubMed] 
84. Yoo, S.M.; Lee, S.Y. Optical biosensors for the detection of pathogenic microorganisms. Trends Biotechnol. 2016, 34, 7-25. [CrossRef] [PubMed]

85. Pérez-López, B.; Merkoçi, A. Nanomaterials based biosensors for food analysis applications. Trends Food Sci. Technol. 2011, 22, 625-639. [CrossRef]

86. Mohanraj, V.; Chen, Y. Nanoparticles: A review. Trop. J. Pharm. Res. 2006, 5, 561-573. [CrossRef]

87. Kurbanoglu, S.; Ozkan, S.A.; Merkoçi, A. Nanomaterials-based enzyme electrochemical biosensors operating through inhibition for biosensing applications. Biosens. Bioelectron. 2017, 89, 886-898. [CrossRef] [PubMed]

88. Wang, J. Nanomaterial-based electrochemical biosensors. Analyst 2005, 130, 421-426. [CrossRef] [PubMed]

89. Zeng, Y.; Zhu, Z.; Du, D.; Lin, Y. Nanomaterial-based electrochemical biosensors for food safety. J. Electroanal. Chem. 2016, 781, 147-154. [CrossRef]

90. Chen, H.; Zuo, X.; Su, S.; Tang, Z.; Wu, A.; Song, S.; Zhang, D.; Fan, C. An electrochemical sensor for pesticide assays based on carbon nanotube-enhanced acetycholinesterase activity. Analyst 2008, 133, 1182-1186. [CrossRef]

91. Jha, N.; Ramaprabhu, S. Development of Au nanoparticles dispersed carbon nanotube-based biosensor for the detection of paraoxon. Nanoscale 2010, 2, 806-810. [CrossRef]

92. Yang, Y.; Luo, C.; Jia, J.; Sun, Y.; Fu, Q.; Pan, C. A wrinkled Ag/CNTs-PDMS composite film for a high-performance flexible sensor and its applications in human-body single monitoring. Nanomaterials 2019, 9, 850. [CrossRef]

93. Scholl, F.; Morais, P.; Gabriel, R.; Schöning, M.; Siqueira, J.; Caseli, L. Carbon nanotubes arranged as smart interfaces in lipid Langmuir-Blodgett films enhancing the enzymatic properties of penicillinase for biosensing applications. ACS Appl. Mater. Interfaces 2017, 9, 31054-31066. [CrossRef] [PubMed]

94. Pyrzynska, K. Carbon nanotubes as sorbents in the analysis of pesticides. Chemosphere 2011, 83, 1407-1413. [CrossRef] [PubMed]

95. Duran, A.; Tuzen, M.; Soylak, M. Preconcentration of some trace elements via using multiwalled carbon nanotubes as solid phase extraction adsorbent. J. Hazard. Mater. 2009, 169, 466-471. [CrossRef] [PubMed]

96. Liang, P.; Ding, Q.; Song, F. Application of multiwalled carbon nanotubes as solid phase extraction sorbent for preconcentration of trace copper in water samples. J. Sep. Sci. 2005, 28, 2339-2343. [CrossRef]

97. Du, D.; Wang, M.; Zhang, J.; Cai, J.; Tu, H.; Zhang, A. Application of multiwalled carbon nanotubes for solid-phase extraction of organophosphate pesticide. Electrochem. Commun. 2008, 10, 85-89. [CrossRef]

98. Cai, Y.-Q.; Cai, Y.-E.; Mou, S.-F.; Lu, Y.-Q. Multi-walled carbon nanotubes as a solid-phase extraction adsorbent for the determination of chlorophenols in environmental water samples. J. Chromatogr. A 2005, 1081, $245-247$. [CrossRef]

99. Su, R.; Xu, X.; Wang, X.; Li, D.; Li, X.; Zhang, H.; Yu, A. Determination of organophosphorus pesticides in peanut oil by dispersive solid phase extraction gas chromatography-mass spectrometry. J. Chromatogr. B 2011, 879, 3423-3428. [CrossRef]

100. Zhu, X.; Cui, Y.; Chang, X.; Wang, H. Selective solid-phase extraction and analysis of trace-level Cr (III), $\mathrm{Fe}$ (III), $\mathrm{Pb}$ (II), and $\mathrm{Mn}$ (II) Ions in wastewater using diethylenetriamine-functionalized carbon nanotubes dispersed in graphene oxide colloids. Talanta 2016, 146, 358-363. [CrossRef]

101. Asensio-Ramos, M.; Hernández-Borges, J.; Borges-Miquel, T.; Rodríguez-Delgado, M. Evaluation of multi-walled carbon nanotubes as solid-phase extraction adsorbents of pesticides from agricultural, ornamental and forestal soils. Anal. Chim. Acta 2009, 647, 167-176. [CrossRef]

102. Wang, J.-X.; Jiang, D.-Q.; Gu, Z.-Y.; Yan, X.-P. Multiwalled carbon nanotubes coated fibers for solid-phase microextraction of polybrominated diphenyl ethers in water and milk samples before gas chromatography with electron-capture detection. J. Chromatogr. A 2006, 1137, 8-14. [CrossRef]

103. Wu, F.; Lu, W.; Chen, J.; Liu, W.; Zhang, L. Single-walled carbon nanotubes coated fibers for solid-phase microextraction and gas chromatography-mass spectrometric determination of pesticides in Tea samples. Talanta 2010, 82, 1038-1043. [CrossRef] [PubMed]

104. Lü, J.; Liu, J.; Wei, Y.; Jiang, K.; Fan, S.; Liu, J.; Jiang, G. Preparation of single-walled carbon nanotube fiber coating for solid-phase microextraction of organochlorine pesticides in lake water and wastewater. J. Sep. Sci. 2007, 30, 2138-2143. [CrossRef] [PubMed]

105. Saraji, M.; Jafari, M.T.; Mossaddegh, M. Carbon nanotubes@ silicon dioxide nanohybrids coating for solid-phase microextraction of organophosphorus pesticides followed by gas chromatography-corona discharge ion mobility spectrometric detection. J. Chromatogr. A 2016, 1429, 30-39. [CrossRef] [PubMed] 
106. Wu, M.; Wang, L.; Zeng, B.; Zhao, F. Ionic liquid polymer functionalized carbon nanotubes-doped poly (3, 4-ethylenedioxythiophene) for highly-efficient solid-phase microextraction of carbamate pesticides. J. Chromatogr. A 2016, 1444, 42-49. [CrossRef]

107. López-Feria, S.; Cárdenas, S.; Valcárcel, M. One step carbon nanotubes-based solid-phase extraction for the gas chromatographic-mass spectrometric multiclass pesticide control in virgin olive oils. J. Chromatogr. A 2009, 1216, 7346-7350. [CrossRef] [PubMed]

108. Yao, Y.; Xu, F.; Chen, M.; Xu, Z.; Zhu, Z. Adsorption behavior of methylene blue on carbon nanotubes. Bioresource Technol. 2010, 101, 3040-3046. [CrossRef]

109. Poizot, P.; Laruelle, S.; Grugeon, S.; Dupont, L.; Tarascon, J. Nano-sized transition-metal oxides as negative-electrode materials for lithium-ion batteries. Nature 2000, 407, 496-499. [CrossRef]

110. Frackowiak, E.; Beguin, F. Electrochemical storage of energy in carbon nanotubes and nanostructured carbons. Carbon 2002, 40, 1775-1787. [CrossRef]

111. Chen, W.X.; Lee, J.Y.; Liu, Z. The nanocomposites of carbon nanotube with Sb and SnSb 0.5 as Li-ion battery anodes. Carbon 2003, 41, 959-966. [CrossRef]

112. Guoping, W.; Qingtang, Z.; Zuolong, Y.; MeiZheng, Q. The effect of different kinds of nano-carbon conductive additives in lithium ion batteries on the resistance and electrochemical behavior of the $\mathrm{LiCoO}_{2}$ composite cathodes. Solid State Ion. 2008, 179, 263-268. [CrossRef]

113. Maurin, G.; Bousquet, C.; Henn, F.; Bernier, P.; Almairac, R.; Simon, B. Electrochemical lithium intercalation into multiwall carbon nanotubes: A micro-Raman study. Solid State Ion. 2000, 136, 1295-1299. [CrossRef]

114. Yang, Z.-H.; Wu, H.-Q. Electrochemical intercalation of lithium into raw carbon nanotubes. Mater. Chem. Phys. 2001, 71, 7-11. [CrossRef]

115. Yang, S.; Song, H.; Chen, X.; Okotrub, A.; Bulusheva, L. Electrochemical performance of arc-produced carbon nanotubes as anode material for lithium-ion batteries. Electrochim. Acta 2007, 52, 5286-5293. [CrossRef]

116. Wu, G.; Wang, C.; Zhang, X.; Yang, H.; Qi, Z.; He, P.; Li, W.Z. Structure and lithium insertion properties of carbon nanotubes. J. Electrochem. Soc. 1999, 146, 1696-1701. [CrossRef]

117. Wang, G.; Ahn, J.-H.; Yao, J.; Lindsay, M.; Liu, H.; Dou, S. Preparation and characterization of carbon nanotubes for energy storage. J. Power Sources 2003, 119, 16-23. [CrossRef]

118. Eom, J.; Kwon, H.; Liu, J.; Zhou, O. Lithium insertion into purified and etched multi-walled carbon nanotubes synthesized on supported catalysts by thermal CVD. Carbon 2004, 42, 2589-2596. [CrossRef]

119. Yang, S.; Huo, J.; Song, H.; Chen, X. A comparative study of electrochemical properties of two kinds of carbon nanotubes as anode materials for lithium ion batteries. Electrochim. Acta 2008, 53, 2238-2244. [CrossRef]

120. Kawasaki, S.; Hara, T.; Iwai, Y.; Suzuki, Y. Metallic and semiconducting single-walled carbon nanotubes as the anode material of Li ion secondary battery. Mater. Lett. 2008, 62, 2917-2920. [CrossRef]

121. De las Casas, C.; Li, W. A review of application of carbon nanotubes for lithium ion battery anode material. J. Power Sources 2012, 208, 74-85. [CrossRef]

122. Chen, M.; Liu, J.; Chao, D.; Wang, J.; Yin, J.; Lin, J.; Fan, H.J.; Shen, Z.X. Porous $\alpha-\mathrm{Fe}_{2} \mathrm{O}_{3}$ nanorods supported on carbon nanotubes-graphene foam as superior anode for lithium ion batteries. Nano Energy 2014, 9, 364-372. [CrossRef]

123. Cohn, A.P.; Oakes, L.; Carter, R.; Chatterjee, S.; Westover, A.S.; Share, K.; Pint, C.L. Assessing the improved performance of freestanding, flexible graphene and carbon nanotube hybrid foams for lithium ion battery anodes. Nanoscale 2014, 6, 4669-4675. [CrossRef] [PubMed]

124. Huang, X.; Yu, H.; Tan, H.; Zhu, J.; Zhang, W.; Wang, C.; Zhang, J.; Wang, Y.; Lv, Y.; Zeng, Z.; et al. Carbon Nanotube-Encapsulated Noble Metal Nanoparticle Hybrid as a Cathode Material for Li-Oxygen Batteries. Adv. Funct. Mater. 2014, 24, 6516-6523. [CrossRef]

125. Wang, G.; Shen, X.; Yao, J.; Wexler, D.; Ahn, J.-H. Hydrothermal synthesis of carbon nanotube/cobalt oxide core-shell one-dimensional nanocomposite and application as an anode material for lithium-ion batteries. Electrochem. Commun. 2009, 11, 546-549. [CrossRef]

126. Qin, L.; Liang, S.; Pan, A.; Tan, X. $\mathrm{Zn}_{2} \mathrm{SnO}_{4} /$ carbon nanotubes composite with enhanced electrochemical performance as anode materials for lithium-ion batteries. Mater. Lett. 2016, 164, 44-47. [CrossRef]

127. Lee, J.H.; Yoon, C.S.; Hwang, J.-Y.; Kim, S.-J.; Maglia, F.; Lamp, P.; Myung, S.T.; Sun, Y.K. High-energy-density lithium-ion battery using a carbon-nanotube-Si composite anode and a compositionally graded $\mathrm{Li}$ $\left[\mathrm{Ni}_{0.85} \mathrm{Co}_{0.05} \mathrm{Mn}_{0.10}\right] \mathrm{O}_{2}$ cathode. Energy Environ. Sci. 2016, 9, 2152-2158. [CrossRef] 
128. Garcia, J.; Gomes, H.; Serp, P.; Kalck, P.; Figueiredo, J.; Faria, J. Carbon nanotube supported ruthenium catalysts for the treatment of high strength wastewater with aniline using wet air oxidation. Carbon 2006, 44, 2384-2391. [CrossRef]

129. Sarkar, B.; Mandal, S.; Tsang, Y.; Kumar, P.; Kim, K.; Ok, Y. Designer carbon nanotubes for contaminant removal in water and waste water: A critical review. Sci. Total Environ. 2018, 612, 561-581. [CrossRef]

130. Deligiorgis, A.; Xekoukoulotakis, N.P.; Diamadopoulos, E.; Mantzavinos, D. Electrochemical oxidation of table olive processing wastewater over boron-doped diamond electrodes: Treatment optimization by factorial design. Water Res. 2008, 42, 1229-1237. [CrossRef]

131. Yang, J.; Wang, J.; Jia, J. Improvement of electrochemical wastewater treatment through mass transfer in a seepage carbon nanotube electrode reactor. Environ. Sci. Technol. 2009, 43, 3796-3802. [CrossRef]

132. Chen, G. Electrochemical technologies in wastewater treatment. Sep. Purif. Technol. 2004, 38, 11-41. [CrossRef]

133. Qu, X.; Alvarez, P.J.; Li, Q. Applications of nanotechnology in water and wastewater treatment. Water Res. 2013, 47, 3931-3946. [CrossRef] [PubMed]

134. Mubarak, N.; Sahu, J.; Abdullah, E.; Jayakumar, N. Removal of heavy metals from wastewater using carbon nanotubes. Sep. Purif. Rev. 2014, 43, 311-338. [CrossRef]

135. Simate, G.S.; Iyuke, S.E.; Ndlovu, S.; Heydenrych, M. The heterogeneous coagulation and flocculation of brewery wastewater using carbon nanotubes. Water Res. 2012, 46, 1185-1197. [CrossRef] [PubMed]

136. Zhang, L.; $\mathrm{Xu}$, L.; He, J.; Zhang, J. Preparation of $\mathrm{Ti} / \mathrm{SnO}_{2}-\mathrm{Sb}$ electrodes modified by carbon nanotube for anodic oxidation of dye wastewater and combination with nanofiltration. Electrochim. Acta 2014, 117, 192-201. [CrossRef]

137. Liu, Y.; Xie, J.; Ong, C.N.; Vecitis, C.D.; Zhou, Z. Electrochemical wastewater treatment with carbon nanotube filters coupled with in situ generated $\mathrm{H}_{2} \mathrm{O}_{2}$. Environ. Sci. Water Res. Technol. 2015, 1, 769-778. [CrossRef]

138. Wang, B.; Li, F.; Yang, P.; Yang, Y.; Hu, J.; Wei, J.; Yu, Q. In situ synthesis of diatomite-carbon Nanotube composite adsorbent and its adsorption characteristics for phenolic compounds. J. Chem. Eng. Data. 2016, 64, 360-371. [CrossRef]

139. Ma, J.; Ma, Y.; Yu, F. A novel one-pot route for large-scale synthesis of novel magnetic CNTs/Fe@C hybrids and their applications for binnary dye removal. ACS Sustain. Chem. Eng. 2018, 6, 8178-8191. [CrossRef]

140. Lee, J.; Ye, Y.; Ward, A.; Zhou, C.; Chen, V.; Minett, A.; Lee, S.; Liu, Z.; Chae, S.; Shi, J. High flux and high selectivity carbon nanotube composite membranes for natural organic matter removal. Sep. Purif. Technol. 2016, 163, 109-119. [CrossRef]

141. Qu, Y.; Ma, Q.; Deng, J.; Shen, W.; Zhang, X.; He, Z.; Nostrand, J.D.; Zhou, J.; Zhou, J. Responses of microbial communities to single-walled carbon nanotubes in phenol wastewater treatment systems. Enviorn. Sci. Technol. 2015, 49, 4627-4635. [CrossRef]

142. Song, Y.-C.; Woo, J.-H.; Yoo, K.-S. Materials for microbial fuel cell: Electrodes, separator and current collector. J. Korean Soc. Environ. Eng. 2009, 31, 693-704.

143. Lovat, V.; Pantarotto, D.; Lagostena, L.; Cacciari, B.; Grandolfo, M.; Righi, M.; Spalluto, G.; Prato, M.; Ballerini, L. Carbon nanotube substrates boost neuronal electrical signaling. Nano Lett. 2005, 5, 1107-1110. [CrossRef] [PubMed]

144. Wang, H.; Wu, Z.; Plaseied, A.; Jenkins, P.; Simpson, L.; Engtrakul, C.; Ren, Z. Carbon nanotube modified air-cathodes for electricity production in microbial fuel cells. J. Power Sources 2011, 196, 7465-7469. [CrossRef]

145. Ghasemi, M.; Daud, W.R.W.; Hassan, S.H.; Jafary, T.; Rahimnejad, M.; Ahmad, A.; Yazdio, M.H. Carbon nanotube/polypyrrole nanocomposite as a novel cathode catalyst and proper alternative for Pt in microbial fuel cell. Int. J. Hydrogen Energy 2016, 41, 4872-4878. [CrossRef]

146. Hou, Y.; Yuan, H.; Wen, Z.; Cui, S.; Guo, X.; He, Z.; Chen, J. Nitrogen-doped graphene/CoNi alloy encased within bamboo-like carbon nanotube hybrids as cathode catalysts in microbial fuel cells. J. Power Sources 2016, 307, 561-568. [CrossRef]

147. He, Y.-R.; Du, F.; Huang, Y.-X.; Dai, L.-M.; Li, W.-W.; Yu, H.-Q. Preparation of microvillus-like nitrogen-doped carbon nanotubes as the cathode of a microbial fuel cell. J. Mater. Chem. A 2016, 4, 1632-1636. [CrossRef]

148. Sanchez, D.V.; Huynh, P.; Kozlov, M.E.; Baughman, R.H.; Vidic, R.D.; Yun, M. Carbon nanotube/platinum (Pt) sheet as an improved cathode for microbial fuel cells. Energy Fuels 2010, 24, 5897-5902. [CrossRef]

149. Ghasemi, M.; Ismail, M.; Kamarudin, S.K.; Saeedfar, K.; Daud, W.R.W.; Hassan, S.H.; Heng, L.Y.; Alam, J.; Oh, S.E. Carbon nanotube as an alternative cathode support and catalyst for microbial fuel cells. Appl. Energy 2013, 102, 1050-1056. [CrossRef] 
150. Ghasemi, M.; Shahgaldi, S.; Ismail, M.; Kim, B.H.; Yaakob, Z.; Daud, W.R.W. Activated carbon nanofibers as an alternative cathode catalyst to platinum in a two-chamber microbial fuel cell. Int. J. Hydrogen Energy 2011, 36, 13746-13752. [CrossRef]

151. Feng, L.; Yan, Y.; Chen, Y.; Wang, L. Nitrogen-doped carbon nanotubes as efficient and durable metal-free cathodic catalysts for oxygen reduction in microbial fuel cells. Energy Environ. Sci. 2011, 4, 1892-1899. [CrossRef]

152. Zou, L.; Qiao, Y.; Wu, X.-S.; Li, C.M. Tailoring hierarchically porous graphene architecture by carbon nanotube to accelerate extracellular electron transfer of anodic biofilm in microbial fuel cells. J. Power Sources 2016, 328, 143-150. [CrossRef]

153. Ren, H.; Pyo, S.; Lee, J.-I.; Park, T.-J.; Gittleson, F.S.; Leung, F.C.; Kim, J.; Taylor, A.D.; Lee, H.S.; Chae, J. A high power density miniaturized microbial fuel cell having carbon nanotube anodes. J. Power Sources 2015, 273, 823-830. [CrossRef]

154. Qiao, Y.; Li, C.M.; Bao, S.-J.; Bao, Q.-L. Carbon nanotube/polyaniline composite as anode material for microbial fuel cells. J. Power Sources 2007, 170, 79-84. [CrossRef]

155. Tsai, H.-Y.; Wu, C.-C.; Lee, C.-Y.; Shih, E.P. Microbial fuel cell performance of multiwall carbon nanotubes on carbon cloth as electrodes. J. Power Sources 2009, 194, 199-205. [CrossRef]

156. Chou, H.-T.; Lee, H.-J.; Lee, C.-Y.; Tai, N.-H.; Chang, H.-Y. Highly durable anodes of microbial fuel cells using a reduced graphene oxide/carbon nanotube-coated scaffold. Bioresource Technol. 2014, 169, 532-536. [CrossRef] [PubMed]

157. Yu, D.; Goh, K.; Wang, H.; Wei, L.; Jiang, W.; Zhang, Q.; Dai, L.; Chen, Y. Scalable synthesis of hierarchically structured carbon nanotube-graphene fibres for capacitive energy storage. Nat. Nanotechnol. 2014, 9, 555-562. [CrossRef] [PubMed]

158. Nützenadel, C.; Züttel, A.; Chartouni, D.; Schlapbach, L. Electrochemical storage of hydrogen in nanotube materials. Electrochem. Solid State Lett. 1999, 2, 30-32. [CrossRef]

159. Cheng, H.-M.; Yang, Q.-H.; Liu, C. Hydrogen storage in carbon nanotubes. Carbon 2001, 39, $1447-1454$. [CrossRef]

160. Dresselhaus, M.; Williams, K.; Eklund, P. Hydrogen adsorption in carbon materials. Mrs Bull. 1999, $24,45-50$. [CrossRef]

161. Panella, B.; Hirscher, M.; Roth, S. Hydrogen adsorption in different carbon nanostructures. Carbon 2005, 43, 2209-2214. [CrossRef]

162. Jordá-Beneyto, M.; Suárez-García, F.; Lozano-Castelló, D.; Cazorla-Amorós, D.; Linares-Solano, A. Hydrogen storage on chemically activated carbons and carbon nanomaterials at high pressures. Carbon 2007, 45, 293-303. [CrossRef]

163. Ariharan, A.; Viswanathan, B.; Nandhakumar, V. Hydrogen storage on boron substituted carbon materials. Int. J. Hydrogen Energy 2016, 41, 3527-3536. [CrossRef]

164. Zhao, T.; Ji, X.; Jin, W.; Yang, W.; Li, T. Hydrogen storage capacity of single-walled carbon nanotube prepared by a modified arc discharge. Fuller. Nanotubes Carbon Nanostruct. 2017, 25, 355-358. [CrossRef]

165. Silambarasan, D.; Surya, V.; Vasu, V.; Iyakutti, K. One-step process of hydrogen storage in single walled carbon nanotubes-tin oxide nano composite. Int. J. Hydrogen Energy 2013, 38, 4011-4016. [CrossRef]

166. Cho, J.H.; Yang, S.J.; Lee, K.; Park, C.R. Si-doping effect on the enhanced hydrogen storage of single walled carbon nanotubes and graphene. Int. J. Hydrogen Energy 2011, 36, 12286-12295. [CrossRef]

167. Shin, W.H.; Jeong, H.M.; Kim, B.G.; Kang, J.K.; Choi, J.W. Nitrogen-doped multiwall carbon nanotubes for lithium storage with extremely high capacity. Nano Lett. 2012, 12, 2283-2288. [CrossRef] [PubMed]

168. Shimoda, H.; Gao, B.; Tang, X.; Kleinhammes, A.; Fleming, L.; Wu, Y.; Zhou, O. Lithium intercalation into opened single-wall carbon nanotubes: Storage capacity and electronic properties. Phys. Rev. Lett. 2001, 88, 015502. [CrossRef]

169. Frackowiak, E.; Metenier, K.; Bertagna, V.; Beguin, F. Supercapacitor electrodes from multiwalled carbon nanotubes. Appl. Phys. Lett. 2000, 77, 2421-2423. [CrossRef]

170. Wang, Y.; Fugetsu, B.; Wang, Z.; Gong, W.; Sakata, I.; Morimoto, S.; Hashimoto, Y.; Endo, M.; Dresselhaus, M.; Terrones, M. Nitrogen-doped porous carbon monoliths from polyacrylonitrile (PAN) and carbon nanotubes as electrodes for supercapacitors. Sci. Rep. 2017, 7, 40259. [CrossRef] 
171. Cheng, Y.; Lu, S.; Zhang, H.; Varanasi, C.V.; Liu, J. Synergistic effects from graphene and carbon nanotubes enable flexible and robust electrodes for high-performance supercapacitors. Nano Lett. 2012, 12, 4206-4211. [CrossRef]

172. Futaba, D.N.; Hata, K.; Yamada, T.; Hiraoka, T.; Hayamizu, Y.; Kakudate, Y.; Tanaike, O.; Hatori, H.; Yumura, M.; Iijima, S. Shape-engineerable and highly densely packed single-walled carbon nanotubes and their application as super-capacitor electrodes. Nat. Mater. 2006, 5, 987-994. [CrossRef]

173. Pham, D.T.; Lee, T.H.; Luong, D.H.; Yao, F.; Ghosh, A.; Le, V.T.; Kim, T.H.; Li, B.; Chang, J.; Lee, Y.H. Carbon nanotube-bridged graphene 3D building blocks for ultrafast compact supercapacitors. ACS Nano 2015, 9, 2018-2027. [CrossRef] [PubMed]

174. Froudakis, G. Hydrogen storage in nanotubes \& nanostructures. Mater. Today 2011, 14, 324-328.

(C) 2020 by the authors. Licensee MDPI, Basel, Switzerland. This article is an open access article distributed under the terms and conditions of the Creative Commons Attribution (CC BY) license (http://creativecommons.org/licenses/by/4.0/). 